\title{
Chemical Composition and Pharmacological Effects of Geopropolis Produced by Melipona quadrifasciata anthidioides
}

\author{
Cintia Miranda dos Santos, ${ }^{1}$ Jaqueline Ferreira Campos, ${ }^{1}$ Helder Freitas dos Santos, ${ }^{1}$ \\ José Benedito Perrella Balestieri, ${ }^{1}$ Denise Brentan Silva, ${ }^{2}$ Kely de Picoli Souza, \\ Carlos Alexandre Carollo, ${ }^{2}$ Leticia M. Estevinho, ${ }^{3,4}$ and Edson Lucas dos Santos ${ }^{1}$
}

\author{
${ }^{1}$ Research Group on Biotechnology and Bioprospecting Applied to Metabolism (GEBBAM), Federal University of Grande Dourados, \\ Rodovia Dourados Itahum, Km 12, 79804-970 Dourados, MS, Brazil \\ ${ }^{2}$ Laboratory of Natural Products and Mass Spectrometry, Federal University of Mato Grosso do Sul, Cidade Universitária, \\ 79070-900 Campo Grande, MS, Brazil \\ ${ }^{3}$ Agricultural College of Bragança, Polytechnic Institute of Bragança, Campus Santa Apolónia, 5301-855 Bragança, Portugal \\ ${ }^{4}$ Molecular and Environmental Biology Centre (CBMA), Universidade do Minho, Campus de Gualtar, 4710057 Braga, Portugal
}

Correspondence should be addressed to Edson Lucas dos Santos; edsonsantosphd@gmail.com

Received 31 July 2017; Accepted 24 September 2017; Published 26 October 2017

Academic Editor: Kota V. Ramana

Copyright ( $) 2017$ Cintia Miranda dos Santos et al. This is an open access article distributed under the Creative Commons Attribution License, which permits unrestricted use, distribution, and reproduction in any medium, provided the original work is properly cited.

\begin{abstract}
Stingless bees produce geopropolis, which is popularly described for its medicinal properties, but for which few scientific studies have demonstrated pharmacological effects. The objective of this study was to investigate the chemical composition of the geopropolis of Melipona quadrifasciata anthidioides and to evaluate its antioxidant, antimutagenic, anti-inflammatory, and antimicrobial activities. The composition of the hydroethanolic extract of geopropolis (HEG) included di- and trigalloyl and phenylpropanyl heteroside derivatives, flavanones, diterpenes, and triterpenes. HEG showed antioxidant action via the direct capture of free radicals and by inhibiting the levels of oxidative hemolysis and malondialdehyde in human erythrocytes under oxidative stress. HEG also reduced the frequency of gene conversion and the number of mutant colonies of S. cerevisiae. The anti-inflammatory action of HEG was demonstrated by the inhibition of hyaluronidase enzyme activity. In addition, HEG induced cell death in all evaluated gram-positive bacteria, gram-negative bacteria, and yeasts, including clinical isolates with antimicrobial drug resistance. Collectively, these results demonstrate the potential of M. q. anthidioides geopropolis for the prevention and treatment of various diseases related to oxidative stress, mutagenesis, inflammatory processes, and microbial infections.
\end{abstract}

\section{Introduction}

Geopropolis is produced by stingless bees (Hymenoptera, Apidae, and Meliponinae) [1] from a mixture of wax, pollen, and the mandibular secretions of bees together with plant resins and the addition of soil, which characterizes and differentiates this material $[2,3]$. Geopropolis is deposited in the hive to seal cracks, delimit the cavities where bees reside, and prevent excessive air entry [4].
Analyses of the chemical compositions of geopropolis samples produced by different species of bees have demonstrated the complexity of this natural product, which contains phenolic compounds such as benzophenones [5], phenolic acids, hydrolysable tannins, and flavonoids $[1,6,7]$, in addition to terpenes and long-chain fatty acids $[8,9]$.

The compounds found in geopropolis are likely responsible for the biological activities that have been 
described in several studies, including antimicrobial $[7,10,11]$, anti-inflammatory $[2,12,13]$, antinociceptive [14], gastroprotective [15], antioxidant [1, 6, 16], antiproliferative [5, 11], antimutagenic [7], and cytotoxic [17, 18] activities.

Among stingless bee species, Melipona quadrifasciata Lepeletier, 1836, popularly known as mandaçaia, is found in much of the Brazilian territory and is subdivided into two subspecies, $M$. quadrifasciata quadrifasciata and $M$. quadrifasciata anthidioides $[19,20]$, which are well described in the literature with respect to development and genetic diversity [19, 21-23]. However, studies examining the chemical composition and therapeutic properties of the natural products produced by these subspecies, such as honey, propolis, and geopropolis, remain scarce.

Kujumgiev et al. [24] described the presence of aromatic acids and di- and triterpene in the propolis produced by M. q. anthidioides and revealed its antimicrobial action against Staphylococcus aureus, Escherichia coli, and Candida albicans. Velikova et al. [25] attributed the inhibition of $S$. aureus by the propolis of $M$. q. anthidioides to the presence of the diterpene kaurenoic acid. Recently, Bonamigo et al. [26] described the presence of several other compounds in the propolis of this bee subspecies, such as stigmasterol, taraxasterol, vanillic acid, caffeic acid, quercetin, luteolin, and apigenin, and demonstrated its antioxidant and cytotoxic action.

With respect to the geopropolis of this subspecies, only Bankova et al. [8] investigated its chemical composition, demonstrating the presence of compounds such as palmitic acid, oleic acid, benzoic acid, cinnamic acid, vanillin, and coniferaldehyde. In this context, the objective of this study was to determine the chemical composition of the hydroethanolic extract of the geopropolis produced by the stingless bee $M$. q. anthidioides, found in the state of Mato Grosso do Sul, Brazil, and to examine its antioxidant, antimutagenic, anti-inflammatory, and antimicrobial activities.

\section{Materials and Methods}

2.1. Collection of Geopropolis Samples. Samples of M. q. anthidioides bee geopropolis were collected at the geographic coordinates $22^{\circ} 13^{\prime} 12^{\prime \prime} \mathrm{S}$ and $54^{\circ} 49^{\prime} 2^{\prime \prime} \mathrm{W}$ in the state of Mato Grosso do Sul, which is in the Central-West region of Brazil. Samples were stored at $-20^{\circ} \mathrm{C}$ until analysis.

2.2. Preparation of the Hydroethanolic Extract of Geopropolis. The hydroethanolic extract of geopropolis (HEG) was prepared from $80 \mathrm{~g}$ of geopropolis and $240 \mathrm{~mL}$ of $70 \%$ ethanol. The mixture was continuously stirred $(165 \mathrm{rpm})$ for $24 \mathrm{~h}$ at room temperature before being filtered. The extract was then concentrated in a rotary evaporator (Gehaka, São Paulo, SP, Brazil) at $40^{\circ} \mathrm{C}$ and lyophilized to obtain a dried extract. The yield was $4.8 \%$, and the material was stored in the dark at $-20^{\circ} \mathrm{C}$.

2.3. Determination of Phenolic Compounds and Flavonoids. The concentration of phenolic compounds in HEG was determined by the Folin-Ciocalteu colorimetric method
[27]. To this end, $0.5 \mathrm{~mL}$ of extract $(100 \mu \mathrm{g} / \mathrm{mL})$ was added to $2.5 \mathrm{~mL}$ of the Folin-Ciocalteu reagent and $2 \mathrm{~mL}$ of sodium carbonate solution $\left(\mathrm{Na}_{2} \mathrm{CO}_{3}\right)$. The mixture was incubated for $2 \mathrm{~h}$ at room temperature in the dark before its absorbance was measured at $760 \mathrm{~nm}$ in a spectrophotometer (PG Instruments Limited, Leicestershire, UK). Gallic acid $(0.4-11 \mu \mathrm{g} / \mathrm{mL})$ was used as the standard to produce the calibration curve. The average of three readings was used to determine the content of phenolic compounds, expressed as mg of gallic acid equivalents per gram of extract (mg GAE/g extract).

The concentration of flavonoids was determined using the method described by Liberio et al. [2] with minor modifications. Specifically, $0.5 \mathrm{~mL}$ of extract $(100 \mu \mathrm{g} / \mathrm{mL})$ was added to $4.5 \mathrm{~mL}$ of methanolic solution of $2 \%$ aluminum chloride hexahydrate $\left(\mathrm{AlCl}_{3} \cdot 6 \mathrm{H}_{2} \mathrm{O}\right)$. The mixture was incubated for $30 \mathrm{~min}$ at room temperature in the dark before its absorbance was measured at $415 \mathrm{~nm}$ in a spectrophotometer (PG Instruments Limited, Leicestershire, $\mathrm{UK})$. Quercetin $(0.4-11 \mu \mathrm{g} / \mathrm{mL})$ was used as the standard to produce the calibration curve. The mean of three readings was used to determine the flavonoid content, expressed as $\mathrm{mg}$ of quercetin equivalent per gram of extract (mg QE/g extract).

2.4. Analysis of HEG by High-Performance Liquid Chromatography Coupled to a Diode Array Detector and Tandem Mass Spectrometry (HPLC-DAD-MS/MS). Five microliters of HEG $(1 \mathrm{mg} / \mathrm{mL})$ was injected into an LC20AD ultrafast liquid chromatograph (UFLC) (Shimadzu) connected in line with a diode array detector (DAD) (240$800 \mathrm{~nm}$ ) and a mass spectrometer with electrospray ionization (ESI) and a quadrupole time-of-flight (QTOF) analyzer (120-1200 Da; micrOTOF-Q III, Bruker Daltonics). It was equipped with a C-18 Kinetex column $(150 \mathrm{~mm} \times 2.2 \mathrm{~mm}$ inner diameter, $2.6 \mu \mathrm{m}$ ) with an oven temperature of $50^{\circ} \mathrm{C}$. The mobile phase consisted of deionized water (A) and acetonitrile (B), both containing $0.1 \%$ formic acid, with the following gradient: $0-8 \mathrm{~min}, 3 \% \mathrm{~B} ; 8-30 \mathrm{~min}, 3-25 \% \mathrm{~B}$; and $30-60 \mathrm{~min}, 25-80 \% \mathrm{~B}$. The gradient was followed by washing and reconditioning of the column $(8 \mathrm{~min})$. The flow rate was $0.3 \mathrm{~mL} / \mathrm{min}$.

\subsection{Antioxidant Activity Assays}

2.5.1. DPPH ${ }^{\bullet}$ Free Radical Capture. The 2,2-diphenyl-1picrylhydrazyl (DPPH) radical-scavenging activity of the geopropolis extract was evaluated according to the method described by D. Gupta and R. K. Gupta [28] with modifications. Specifically, $200 \mu \mathrm{L}$ of HEG solubilized in $80 \%$ ethanol $(0.1-200 \mu \mathrm{g} / \mathrm{mL})$ was mixed with $1800 \mu \mathrm{L}$ of the $\mathrm{DPPH}^{\bullet}$ solution $(0.11 \mathrm{mM})$. The mixture was homogenized and incubated for $30 \mathrm{~min}$ at room temperature in the dark before its absorbance was measured at $517 \mathrm{~nm}$ in a spectrophotometer (PG Instruments Limited, Leicestershire, UK). Ascorbic acid and butylated hydroxytoluene (BHT) were used as reference antioxidants. As a negative control, $80 \%$ ethanol alone was incubated with $\mathrm{DPPH}^{\bullet}$ solution. Three independent experiments were performed in duplicate. The percent 
inhibition relative to the negative control was calculated using the following:

$$
\mathrm{DPPH}^{\bullet} \text { inhibition }(\%)=\frac{1-\mathrm{Abs}_{\text {sample }}}{\mathrm{Abs}_{\text {control }}} \times 100 \text {. }
$$

2.5.2. ABTS $^{\circ+}$ Free Radical Scavenging. The antioxidant capacity of HEG was also evaluated by the method described by $\mathrm{Re}$ et al. [29], in which 2,2' -azinobis(3-ethylbenzthiazoline-6-sulfonic acid) (ABTS) free radical-scavenging activity is examined. The ABTS $^{\bullet+}$ radical was formed by mixing $5 \mathrm{~mL}$ of the ABTS solution $(7 \mathrm{mM})$ with $88 \mu \mathrm{L}$ of potassium persulfate solution $(140 \mathrm{mM})$. The mixture was incubated for $12-16 \mathrm{~h}$ at room temperature in the dark before the $\mathrm{ABTS}^{\bullet+}$ radical was diluted in absolute ethanol until it reached an absorbance of $0.70 \pm 0.05$ at $734 \mathrm{~nm}$ in a spectrophotometer (PG Instruments Limited, Leicestershire, UK). Next, $20 \mu \mathrm{L}$ of HEG solubilized in $80 \%$ ethanol $(0.1-200 \mu \mathrm{g} / \mathrm{mL})$ was mixed with $1980 \mu \mathrm{L}$ of the $\mathrm{ABTS}^{\bullet+} \mathrm{rad}-$ ical. The mixture was incubated for $6 \mathrm{~min}$, and its absorbance was then measured at $734 \mathrm{~nm}$. Ascorbic acid and BHT were used as positive controls. As a negative control, $80 \%$ ethanol alone was incubated with the $\mathrm{ABTS}^{\bullet+}$ radical. Two independent experiments were performed in triplicate. The percent inhibition of the $\mathrm{ABTS}^{\bullet+}$ radical relative to the negative control was calculated using the following:

$$
\mathrm{ABTS}^{\bullet+} \text { inhibition }(\%)=\frac{\mathrm{Abs}_{\text {control }}-\mathrm{Abs}_{\text {sample }}}{\mathrm{Abs}_{\text {control }}} \times 100 \text {. }
$$

2.5.3. Inhibition of Oxidative Hemolysis and Lipid Peroxidation in Human Erythrocytes. The procedures performed were approved by the Ethics Committee of the University Center of Grande Dourados (Centro Universitário da Grande Dourados (UNIGRAN)), Brazil (CEP number 123/12). The assays were performed as described by Campos et al. [30].

(1) Preparation of Erythrocyte Suspensions. For the hemolysis inhibition and malondialdehyde assays, $20 \mathrm{~mL}$ of peripheral blood was collected from healthy donors and packed in a tube containing sodium citrate. The blood was centrifuged at $2000 \mathrm{rpm}$ for $10 \mathrm{~min}$, and the plasma and leukocyte layers were removed. The erythrocytes were washed with $0.9 \%$ sodium chloride $(\mathrm{NaCl})$, and a $10 \%$ erythrocyte suspension in $0.9 \% \mathrm{NaCl}$ was further diluted to yield a final erythrocyte concentration of $2.5 \%$ for the experiments.

(2) Hemolytic Activity and Inhibition of Oxidative Hemolysis. To investigate whether HEG promotes hemolysis in erythrocytes, erythrocyte samples were preincubated at $37^{\circ} \mathrm{C}$ for $30 \mathrm{~min}$ in the presence of different concentrations of HEG $(5-75 \mu \mathrm{g} / \mathrm{mL}) ; 0.9 \% \mathrm{NaCl}$ solution was then added, and the mixture was incubated for 240 min with periodic homogenization. The ability of HEG to inhibit oxidative hemolysis was assessed after preincubation of the extract $(5-75 \mu \mathrm{g} / \mathrm{mL})$ with the erythrocytes at $37^{\circ} \mathrm{C}$ for $30 \mathrm{~min}$; the oxidizing agent $2,2^{\prime}$ -azobis(2-amidinopropane)dihydrochloride (AAPH; $50 \mathrm{mM}$ ) was then added, and the mixture was incubated for $240 \mathrm{~min}$ with periodic homogenization. Protection against hemolysis was evaluated after 120,180 , and $240 \mathrm{~min}$ of incubation. Hemolysis was assayed by centrifuging the samples at $1500 \mathrm{rpm}$ for $10 \mathrm{~min}$ and then reading the absorbance of the supernatant at $540 \mathrm{~nm}$ in a spectrophotometer (PG Instruments Limited, Leicestershire, UK). The ascorbic acid control was maintained under the same conditions in both assays. As a solvent control, the erythrocytes were incubated with ethanol at a final concentration of $1 \%$. Three independent experiments were conducted in duplicate. The percentage of hemolysis was calculated using the following formula, where $A$ is the absorbance of the sample and $B$ is the total hemolysis (erythrocytes incubated with distilled water).

$$
\text { Inhibition of hemolysis }(\%)=\frac{A}{B} \times 100 \text {. }
$$

(3) Quantification of Malondialdehyde (MDA). To examine the ability of HEG to protect erythrocytes against lipid peroxidation, the levels of MDA, a byproduct of lipid peroxidation, were quantified. HEG $(5-75 \mu \mathrm{g} / \mathrm{mL})$ was preincubated with an erythrocyte suspension at $37^{\circ} \mathrm{C}$ for $30 \mathrm{~min}$; the oxidizing agent AAPH (50 mM) was then added, and the mixture was incubated for $240 \mathrm{~min}$ with periodic homogenization. After this period, the samples were centrifuged at $1500 \mathrm{rpm}$ for $10 \mathrm{~min}$, and $500 \mu \mathrm{L}$ aliquots of the supernatant was transferred to tubes containing $1 \mathrm{~mL}$ of $10 \mathrm{nM}$ thiobarbituric acid (TBA) solubilized in monosodium potassium phosphate buffer $(75 \mathrm{mM})$ at $\mathrm{pH} 2.5$. As an MDA standard, $500 \mu \mathrm{L}$ of $20 \mathrm{mM}$ MDA solution was added to $1 \mathrm{~mL}$ of TBA. The samples were incubated at $96^{\circ} \mathrm{C}$ for $45 \mathrm{~min}$ before being cooled in an ice bath; $4 \mathrm{~mL}$ of n-butyl alcohol was then added, and the mixture was centrifuged at $3000 \mathrm{rpm}$ for $5 \mathrm{~min}$. The absorbance of the supernatant was read at $540 \mathrm{~nm}$ in a spectrophotometer (PG Instruments Limited, Leicestershire, UK). The ascorbic acid control was maintained under the same conditions. As a solvent control, the erythrocytes were incubated with ethanol at a final concentration of $1 \%$. Three independent experiments were conducted in duplicate. MDA levels are expressed as $\mathrm{nM} / \mathrm{mL}$ and were obtained using the following:

$$
\mathrm{MDA}=\mathrm{Abs}_{\text {sample }} \times \frac{20 \times 220.32}{\mathrm{Abs}_{\mathrm{MDA} \text { standard }}} .
$$

2.6. Antimutagenic Activity. The antimutagenic activity of HEG was determined using Saccharomyces cerevisiae cells (D7 diploid strain of ATCC 201137) according to the method of Pascoal et al. [31]. Before each experiment, S. cerevisiae strains (MATa/MATa, ade2-40/ade 2-119, trp 5-12/trp 5-27, and $I L V$ 1-92/ILV 1-92) were tested for the frequencies of spontaneous conversions at the tryptophan locus and revertants at the isoleucine locus. Cells from a culture with a low frequency of spontaneous gene conversion and a low back mutation (reversion of point mutation) frequency were grown in liquid medium at $28^{\circ} \mathrm{C}$ until they reached a stationary phase. S. cerevisiae cells were sedimented and resuspended in sterile potassium phosphate buffer $(0.1 \mathrm{M}$; $\mathrm{pH} 7.4$ ) to obtain a final concentration of $2 \times 10^{8}$ cells $/ \mathrm{mL}$. As a mutagenic compound, ethyl methanesulfonate (EMS; 
TABLE 1: Microorganisms used in the present study to test the antimicrobial activity of HEG from M. q. anthidioides.

\begin{tabular}{lcc}
\hline Microorganism & Reference & Origin \\
\hline Staphylococcus aureus & ATCC $6538^{\mathrm{TM}}$ & Reference culture \\
Methicillin-resistant $S$. aureus & ESA 175 & Pus \\
Methicillin-resistant $S$. aureus & ESA 159 & Expectoration \\
Enterococcus faecalis & ATCC $43300^{\mathrm{TM}}$ & Reference culture \\
Vancomycin-resistant E. faecalis & ESA 201 & Urine \\
Vancomycin-resistant E. faecalis & ESA 361 & Rectal swabs \\
Escherichia coli & ATCC $29998^{\mathrm{TM}}$ & Reference culture \\
Cephalosporin-resistant E. coli & ESA 37 & Urine \\
Cephalosporin-resistant E. coli & ESA 54 & Hemoculture \\
Pseudomonas aeruginosa & ATCC $15442^{\mathrm{TM}}$ & Reference culture \\
Imipenem-resistant $P$. aeruginosa & ESA 22 & Expectoration \\
Imipenem-resistant $P$. aeruginosa & ESA 23 & Gingival exudates \\
Cryptococcus neoformans & ATCC 32264 & Reference culture \\
Amphotericin B-resistant $C$. neoformans & ESA 211 & Blood \\
Amphotericin B-resistant $C$. neoformans & ESA 105 & Skin biopsy \\
Candida albicans & ATCC $10231^{\mathrm{TM}}$ & Reference culture \\
Amphotericin B-resistant C. albicans & ESA 100 & Feces \\
Amphotericin B-resistant C. albicans & ESA 97 & Urine \\
\hline
\end{tabular}

$1 \mathrm{mg} / \mathrm{mL}$ ) was added and incubated with the cell suspension, the potassium phosphate buffer, and HEG at final concentrations of 1.5 and $3.0 \mathrm{mg} / \mathrm{mL}$. The mixture was incubated with stirring for $2 \mathrm{~h}$ at $37^{\circ} \mathrm{C}$. The cells were then plated on complete and selective media to evaluate survival, tryptophan convertants, and isoleucine revertants. The experiments were performed in triplicate.

2.7. Anti-Inflammatory Activity Assessment by Hyaluronidase Enzyme Inhibition. The anti-inflammatory potential of HEG was evaluated indirectly by examining its inhibition of hyaluronidase enzyme activity according to the method described by Silva et al. [32]. The reaction mixture consisted of $50 \mu \mathrm{L}$ of HEG and $50 \mu \mathrm{L}$ (350 units) of hyaluronidase (type IV-S; bovine testes, Sigma, St. Louis, MO, USA), which was incubated at $37^{\circ} \mathrm{C}$ for $20 \mathrm{~min}$. Next, $1.2 \mu \mathrm{L}$ of calcium chloride $\left(2.5 \times 10^{-3} \mathrm{M}\right)$ was added, and the mixture was incubated at $37^{\circ} \mathrm{C}$ for $20 \mathrm{~min}$ to activate the enzyme. As a substrate, $500 \mu \mathrm{L}$ of hyaluronic acid sodium salt $(0.1 \mathrm{M})$ was added. The mixture was incubated at $37^{\circ} \mathrm{C}$ for $40 \mathrm{~min}, 100 \mu \mathrm{L}$ of potassium tetraborate $(0.8 \mathrm{M})$ was then added, and the mixture was incubated at $100^{\circ} \mathrm{C}$ for $3 \mathrm{~min}$. After cooling the solution, $3 \mathrm{~mL}$ of p-dimethylaminobenzaldehyde was added, and the mixture was incubated at $37^{\circ} \mathrm{C}$ for $20 \mathrm{~min}$. Its absorbance was then measured at $585 \mathrm{~nm}$ in a spectrophotometer (PG Instruments Limited, Leicestershire, UK). Distilled water was used as a control. The experiments were performed in triplicate. The percent inhibition of enzyme activity relative to the control was calculated using the following:

Inhibition of hyaluronidase activity $(\%)=\frac{\mathrm{Abs}_{\text {control }}-\mathrm{Abs}_{\text {sample }}}{\mathrm{Abs}_{\text {control }}} \times 10$.
2.8. Antimicrobial Activity. The microorganisms used in this study are listed in Table 1 . The clinical microorganisms were isolated from biological fluids collected at the Hospital Center and were identified at the Laboratory of Microbiology of the School of Higher Agricultural Education of Bragança (Escola Superior Agrária de Bragança (ESA)), and reference strains were obtained from the American Type Culture Collection (ATCC) (LGC Standards SLU, Barcelona, Spain).

Prior to experimental use, the isolates were maintained in Muller-Hinton medium containing $20 \%$ glycerol at $-70^{\circ} \mathrm{C}$. The inoculum for the assays was prepared by dilution of a cell mass in $0.85 \% \mathrm{NaCl}$ solution to 0.5 on the McFarland scale and confirmed by spectrophotometry at 580 and $640 \mathrm{~nm}$ for bacteria and yeast, respectively. For antimicrobial assays, microorganism suspensions were diluted to $10^{4}$ colonyforming units (CFU)/mL according to the method described by Silva et al. [32]. Nutrient broth (NB) or yeast extractpeptone-dextrose (YPD) was used in microplates (96 wells). The HEG was diluted in dimethyl sulfoxide (DMSO) and transferred to the first well of the plate; serial dilutions were then performed. The inoculum was added to all wells, and the plates were incubated at $37^{\circ} \mathrm{C}$ for $24 \mathrm{~h}$ (bacteria) or at $25^{\circ} \mathrm{C}$ for $48 \mathrm{~h}$ (yeast). As positive controls, the antibiotic gentamicin and the antifungal amphotericin B were used. In addition, media controls were conducted with and without inocula, and DMSO alone was used as a solvent control in inoculated medium. Antimicrobial activity was detected by the addition of $20 \mu \mathrm{L}$ of 2,3,5-triphenyl-2H-tetrazolium chloride (TTC) solution $(5 \mathrm{mg} / \mathrm{mL})$. The minimal inhibitory concentration (MIC) was defined as the lowest concentration of HEG that inhibited visible growth of the microorganisms as indicated by TTC staining of living cells.

To determine the minimum bactericidal concentration (MBC) and minimum fungicidal concentration (MFC), 


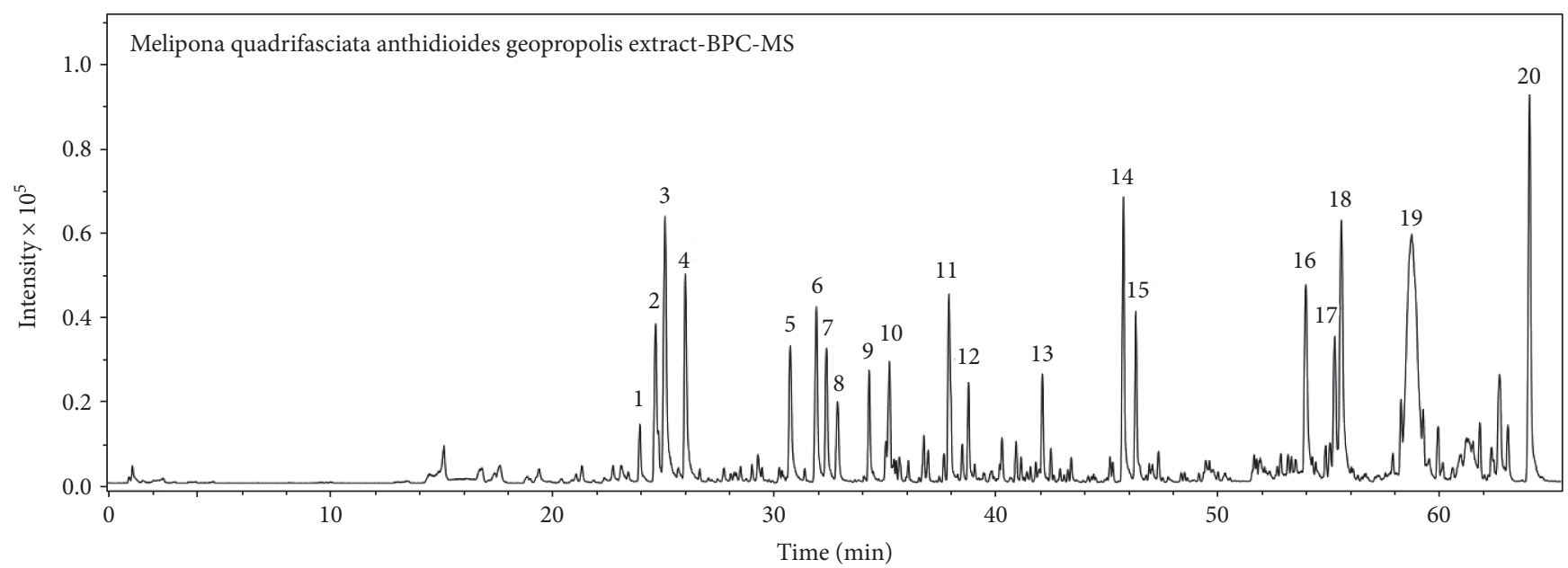

Figure 1: Base peak chromatogram of M. q. anthidioides geopropolis extract. Peaks 1 to 20 are identified in Table 1.

$20 \mu \mathrm{L}$ samples was collected from the last well where growth was observed and from each well that did not show a change in staining, and the samples were plated on NB or YPD and incubated at $37^{\circ} \mathrm{C}$ for $24 \mathrm{~h}$ (bacteria) or at $25^{\circ} \mathrm{C}$ for $48 \mathrm{~h}$ (yeast). The MBC or MFC was defined as the lowest concentration that did not result in growth $(<10 \mathrm{CFU} /$ plate $)$ after cultivation. The results are expressed as $\mathrm{mg} / \mathrm{mL}$, and the experiments were performed in triplicate.

2.9. Statistical Analyses. The data are expressed as the mean \pm standard error of the mean (SEM) and were evaluated by ANOVA followed by the Dunnett's test using GraphPad Prism Software version 5.0 (GraphPad Software Inc., San Diego, CA, USA). The results were considered significant when $P<0.05$.

\section{Results}

3.1. Chemical Composition. The total concentrations of phenolic compounds and flavonoids present in HEG were $118.7 \pm 2.8 \mathrm{mg} \mathrm{GAE} / \mathrm{g}$ extract and $25.4 \pm 2.8 \mathrm{mg} \mathrm{QE} / \mathrm{g}$ extract, respectively.

Peaks 1, 2, 4, 5, 6, 7, 9, 11, and 12 showed similar UV spectra and MS/MS fragments. The UV absorbance of the compounds was centered at approximately $300 \mathrm{~nm}$, and the observed variations were compatible with the presence of different moieties (Figure 1, Table 2). All of these compounds exhibited a central hexose with two or three galloyl, cinnamoyl, or coumaroyl groups. Certain key fragments supported putative identities of the peaks, such as $\mathrm{m} / z 169$ $\left(\mathrm{C}_{7} \mathrm{H}_{5} \mathrm{O}_{5}\right)^{-}$, related to gallic acid, observed in compounds 2 , $3,4,5,6,9$, and $12 ; \mathrm{m} / z 313\left(\mathrm{C}_{13} \mathrm{H}_{13} \mathrm{O}_{9}\right)^{-}$, related to a galloyl-hexoside fragment, detected in compounds $1,2,4,6$, 9 , and 12; and $m / z 465\left(\mathrm{C}_{20} \mathrm{H}_{17} \mathrm{O}_{13}\right)^{-}$, related to a digalloylhexoside moiety, observed in compounds 4 and 6 . Other fragments yielded less information, as in the case of $\mathrm{m} / z$ $265\left(\mathrm{C}_{13} \mathrm{H}_{13} \mathrm{O}_{6}\right)^{-}, m / z 235\left(\mathrm{C}_{12} \mathrm{H}_{11} \mathrm{O}_{5}\right)^{-}$, and $\mathrm{m} / z 205$ $\left(\mathrm{C}_{11} \mathrm{H}_{9} \mathrm{O}_{4}\right)^{-}$in compound 2 or $\mathrm{m} / z$ $145\left(\mathrm{C}_{9} \mathrm{H}_{5} \mathrm{O}_{2}\right)^{-}$in compounds 7 and 8; these fragments are likely the result of substitutions at specific positions of the hexose. Unfortunately, the determination of these sites was not possible due to a lack of information in the literature or a limited access to standards. Thus, compounds were identified as coumaroyl-galloyl-hexoside derivatives (1 and 2), digalloyl-coumaroyl-hexoside (4), cinnamoyl-galloyl-hexoside (5), digalloyl-cinnamoyl-hexoside (6), dicoumaroyl-hexoside (7), dicoumaroyl-galloyl-hexoside (9), cinnamoyl-coumaroylhexoside (11), and cinnamoyl-coumaroyl-galloyl-hexoside (12); compounds of this class were also isolated from the geopropolis of M. subnitida [1].

The HEG also contained three observed flavanones (peaks 3, 8, and 10). They were characterized based on their UV spectra, high-resolution mass, and fragments such as aromadendrin, naringenin, and methyl aromadendrin, which were previously reported in the geopropolis of Melipona ssp. [1, 16].

The final characterized peaks were detected at the end of the chromatogram (peaks 14, 15, 16, 17, 18, 19, and 20; Figure 1), implying that they were apolar compounds. These peaks did not absorb in the UV-monitored range, and their molecular formulae suggest diterpene (peaks 14 and 15) and triterpene (peaks 16,17, and 18) derivatives. Although these chemical classes are very common in propolis and geopropolis [24, 25], no more information could be obtained due to a lack of fragmentation and the large number of possible skeletons.

Compounds $19\left(\mathrm{C}_{24} \mathrm{H}_{38} \mathrm{O}_{3}\right)$ and $20\left(\mathrm{C}_{24} \mathrm{H}_{36} \mathrm{O}_{3}\right)$ showed similar formulae, differing by only two hydrogens; both showed only one fragment that was related to $\mathrm{CO}_{2}$ loss, suggesting the presence of carboxylic acid in the structure. However, no compatible plant metabolites were found in the literature.

\subsection{Antioxidant Activity}

3.2.1. DPPH ${ }^{\bullet}$ and $\mathrm{ABTS}^{\bullet+}$ Free Radical Scavenging. The HEG displayed relevant antioxidant action in the direct scavenging of the free radicals $\mathrm{DPPH}^{\bullet}$ and $\mathrm{ABTS}^{\bullet+}$. In the $\mathrm{DPPH}^{\bullet}$ assay, 
TABLE 2: Compounds identified from Melipona quadrifasciata anthidioides geopropolis extract by HPLC-DAD-ESI-qTOF-MS/MS.

\begin{tabular}{|c|c|c|c|c|c|c|c|}
\hline Peak & $\mathrm{RT}(\min )$ & UV (nm) & $\operatorname{MS}(m / z)$ & $\begin{array}{l}\text { Molecular } \\
\text { formula }\end{array}$ & $\begin{array}{l}\text { Error } \\
(\mathrm{ppm})\end{array}$ & $\mathrm{MS} / \mathrm{MS}(m / z)$ & Identification \\
\hline 1 & 24 & 289 and 309 & 477.1053 & $\mathrm{C}_{22} \mathrm{H}_{22} \mathrm{O}_{12}$ & 2.9 & $313\left(\mathrm{C}_{13} \mathrm{H}_{13} \mathrm{O}_{9}\right)^{-}, 271\left(\mathrm{C}_{11} \mathrm{H}_{11} \mathrm{O}_{8}\right)^{-}, 169\left(\mathrm{C}_{7} \mathrm{H}_{5} \mathrm{O}_{5}\right)^{-}$ & $\begin{array}{l}\text { Coumaroyl- } \\
\text { galloyl-hexoside }\end{array}$ \\
\hline 2 & 24.7 & 289 and 309 & 477.1040 & $\mathrm{C}_{22} \mathrm{H}_{22} \mathrm{O}_{12}$ & 0.5 & $\begin{array}{c}313\left(\mathrm{C}_{13} \mathrm{H}_{13} \mathrm{O}_{9}\right)^{-}, 265\left(\mathrm{C}_{13} \mathrm{H}_{13} \mathrm{O}_{6}\right)^{-}, 235\left(\mathrm{C}_{12} \mathrm{H}_{11} \mathrm{O}_{5}\right)^{-} \\
205\left(\mathrm{C}_{11} \mathrm{H}_{9} \mathrm{O}_{4}\right)^{-}, 169\left(\mathrm{C}_{7} \mathrm{H}_{5} \mathrm{O}_{5}\right)^{-}\end{array}$ & $\begin{array}{l}\text { Coumaroyl- } \\
\text { galloyl-hexoside }\end{array}$ \\
\hline 3 & 25.1 & 289 & 287.0565 & $\mathrm{C}_{15} \mathrm{H}_{12} \mathrm{O}_{6}$ & 1.6 & $259\left(\mathrm{C}_{14} \mathrm{H}_{11} \mathrm{O}_{5}\right)^{-}, 177\left(\mathrm{C}_{10} \mathrm{H}_{9} \mathrm{O}_{3}\right)^{-}$ & Aromadendrin \\
\hline 4 & 26 & 286 and 308 & 629.1166 & $\mathrm{C}_{29} \mathrm{H}_{26} \mathrm{O}_{16}$ & 3.1 & $\begin{array}{c}465\left(\mathrm{C}_{20} \mathrm{H}_{17} \mathrm{O}_{13}\right)^{-}, 459\left(\mathrm{C}_{22} \mathrm{H}_{19} \mathrm{O}_{11}\right)^{-}, 313 \\
\left(\mathrm{C}_{13} \mathrm{H}_{13} \mathrm{O}_{9}\right)^{-}, 271\left(\mathrm{C}_{11} \mathrm{H}_{11} \mathrm{O}_{8}\right)^{-}, 169\left(\mathrm{C}_{7} \mathrm{H}_{5} \mathrm{O}_{5}\right)^{-}\end{array}$ & $\begin{array}{l}\text { Digalloyl- } \\
\text { coumaroyl- } \\
\text { hexoside }\end{array}$ \\
\hline 5 & 30.8 & 280 & 461.1113 & $\mathrm{C}_{22} \mathrm{H}_{22} \mathrm{O}_{11}$ & 3.7 & $211\left(\mathrm{C}_{9} \mathrm{H}_{7} \mathrm{O}_{6}\right)^{-}, 169\left(\mathrm{C}_{7} \mathrm{H}_{5} \mathrm{O}_{5}\right)^{-}, 161\left(\mathrm{C}_{10} \mathrm{H}_{9} \mathrm{O}_{2}\right)^{-}$ & $\begin{array}{l}\text { Cinnamoyl- } \\
\text { galloyl-hexoside }\end{array}$ \\
\hline 6 & 31.9 & 280 & 613.1216 & $\mathrm{C}_{29} \mathrm{H}_{26} \mathrm{O}_{15}$ & 2.2 & $\begin{array}{c}465\left(\mathrm{C}_{20} \mathrm{H}_{17} \mathrm{O}_{13}\right)^{-}, 313\left(\mathrm{C}_{13} \mathrm{H}_{13} \mathrm{O}_{9}\right)^{-}, 271\left(\mathrm{C}_{11} \mathrm{H}_{11} \mathrm{O}_{8}\right)^{-} \\
211\left(\mathrm{C}_{9} \mathrm{H}_{7} \mathrm{O}_{6}\right)^{-}, 169\left(\mathrm{C}_{7} \mathrm{H}_{5} \mathrm{O}_{5}\right)^{-}\end{array}$ & $\begin{array}{l}\text { Digalloyl- } \\
\text { cinnamoyl- } \\
\text { hexoside }\end{array}$ \\
\hline 7 & 32.4 & 299 and 311 & 471.1324 & $\mathrm{C}_{24} \mathrm{H}_{24} \mathrm{O}_{10}$ & 4.3 & $\begin{array}{c}325\left(\mathrm{C}_{15} \mathrm{H}_{17} \mathrm{O}_{8}\right)^{-}, 307\left(\mathrm{C}_{15} \mathrm{H}_{15} \mathrm{O}_{7}\right)^{-}, 265\left(\mathrm{C}_{13} \mathrm{H}_{13} \mathrm{O}_{6}\right)^{-} \\
163\left(\mathrm{C}_{9} \mathrm{H}_{7} \mathrm{O}_{3}\right)^{-}, 145\left(\mathrm{C}_{9} \mathrm{H}_{5} \mathrm{O}_{2}\right)^{-}\end{array}$ & $\begin{array}{l}\text { Dicoumaroyl- } \\
\text { hexoside }\end{array}$ \\
\hline 8 & 32.9 & 284 & 271.0622 & $\mathrm{C}_{15} \mathrm{H}_{12} \mathrm{O}_{5}$ & 3.2 & - & Naringenin \\
\hline 9 & 34.3 & 290 and 311 & 623.1428 & $\mathrm{C}_{31} \mathrm{H}_{28} \mathrm{O}_{14}$ & 2.2 & $\begin{array}{c}459\left(\mathrm{C}_{22} \mathrm{H}_{19} \mathrm{O}_{11}\right)^{-}, 313\left(\mathrm{C}_{13} \mathrm{H}_{13} \mathrm{O}_{9}\right)^{-}, 271\left(\mathrm{C}_{11} \mathrm{H}_{11} \mathrm{O}_{8}\right)^{-} \\
211\left(\mathrm{C}_{9} \mathrm{H}_{7} \mathrm{O}_{6}\right)^{-}, 169\left(\mathrm{C}_{7} \mathrm{H}_{5} \mathrm{O}_{5}\right)^{-}, 163\left(\mathrm{C}_{9} \mathrm{H}_{7} \mathrm{O}_{3}\right)^{-}\end{array}$ & $\begin{array}{l}\text { Dicoumaroyl- } \\
\text { galloyl-hexoside }\end{array}$ \\
\hline 10 & 35.2 & 290 & 301.0731 & $\mathrm{C}_{16} \mathrm{H}_{14} \mathrm{O}_{6}$ & 2.8 & $\begin{array}{c}273\left(\mathrm{C}_{15} \mathrm{H}_{13} \mathrm{O}_{5}\right)^{-}, 240\left(\mathrm{C}_{14} \mathrm{H}_{8} \mathrm{O}_{4}\right)^{-}, 179\left(\mathrm{C}_{8} \mathrm{H}_{3} \mathrm{O}_{5}\right)^{-}, 165 \\
\left(\mathrm{C}_{8} \mathrm{H}_{5} \mathrm{O}_{4}\right)^{-}\end{array}$ & $\begin{array}{l}\text { Methyl } \\
\text { aromadendrin }\end{array}$ \\
\hline 11 & 37.9 & 285 and 310 & 455.1353 & $\mathrm{C}_{24} \mathrm{H}_{24} \mathrm{O}_{9}$ & 1.2 & $163\left(\mathrm{C}_{9} \mathrm{H}_{7} \mathrm{O}_{3}\right)^{-}, 145\left(\mathrm{C}_{9} \mathrm{H}_{5} \mathrm{O}_{2}\right)^{-}$ & $\begin{array}{l}\text { Cinnamoyl- } \\
\text { coumaroyl- } \\
\text { hexoside }\end{array}$ \\
\hline 12 & 38.8 & 285 and 310 & 607.1455 & $\mathrm{C}_{31} \mathrm{H}_{28} \mathrm{O}_{13}$ & 2.7 & $\begin{array}{c}461\left(\mathrm{C}_{22} \mathrm{H}_{21} \mathrm{O}_{11}\right)^{-}, 443\left(\mathrm{C}_{22} \mathrm{H}_{19} \mathrm{O}_{10}\right)^{-}, 313 \\
\left(\mathrm{C}_{13} \mathrm{H}_{13} \mathrm{O}_{9}\right)^{-}, 271\left(\mathrm{C}_{11} \mathrm{H}_{11} \mathrm{O}_{8}\right)^{-}, 211\left(\mathrm{C}_{9} \mathrm{H}_{7} \mathrm{O}_{6}\right)^{-} \\
169\left(\mathrm{C}_{7} \mathrm{H}_{5} \mathrm{O}_{5}\right)^{-}\end{array}$ & $\begin{array}{l}\text { Cinnamoyl- } \\
\text { coumaroyl- } \\
\text { galloyl-hexoside }\end{array}$ \\
\hline 13 & 42.1 & 295 & 421.1290 & $\mathrm{C}_{24} \mathrm{H}_{22} \mathrm{O}_{7}$ & 0.9 & - & Unknown \\
\hline 14 & 45.7 & - & 319.2272 & $\mathrm{C}_{20} \mathrm{H}_{32} \mathrm{O}_{3}$ & 3.4 & - & Diterpene \\
\hline 15 & 46.3 & - & 319.2270 & $\mathrm{C}_{20} \mathrm{H}_{32} \mathrm{O}_{3}$ & 0.9 & - & Diterpene \\
\hline 16 & 54 & - & 471.3475 & $\mathrm{C}_{30} \mathrm{H}_{48} \mathrm{O}_{4}$ & 0.8 & - & Triterpene \\
\hline 17 & 55.3 & - & 471.3471 & $\mathrm{C}_{30} \mathrm{H}_{48} \mathrm{O}_{4}$ & 3.3 & - & Triterpene \\
\hline 18 & 55.5 & - & 469.3314 & $\mathrm{C}_{30} \mathrm{H}_{46} \mathrm{O}_{4}$ & 3.0 & - & Triterpene \\
\hline 19 & 58.7 & - & 373.2736 & $\mathrm{C}_{24} \mathrm{H}_{38} \mathrm{O}_{3}$ & 2.9 & $329\left(\mathrm{C}_{23} \mathrm{H}_{37} \mathrm{O}\right)^{-}$ & Unknown \\
\hline 20 & 64 & - & 371.2583 & $\mathrm{C}_{24} \mathrm{H}_{36} \mathrm{O}_{3}$ & 3.0 & $327\left(\mathrm{C}_{23} \mathrm{H}_{35} \mathrm{O}\right)^{-}$ & Unknown \\
\hline
\end{tabular}

RT: retention time; - indicates nonobserved/detected means.

HEG inhibited $50 \%$ of the free radicals $\left(\mathrm{IC}_{50}\right)$ at a concentration of $28.9 \pm 1.3 \mu \mathrm{g} / \mathrm{mL}$, an activity 1.7 times lower than that of the antioxidant BHT $\left(\mathrm{IC}_{50}=16.9 \pm 5.2 \mu \mathrm{g} / \mathrm{mL}\right)$ (Figure 2(a)). In the $\mathrm{ABTS}^{\bullet+}$ assay, the HEG showed an $\mathrm{IC}_{50}$ of $9.5 \pm 0.8 \mu \mathrm{g} / \mathrm{mL}$, similar to the synthetic antioxidant BHT $\left(\mathrm{IC}_{50}=8.1 \pm 0.7 \mu \mathrm{g} / \mathrm{mL}\right)$; however, HEG showed five times less activity than the standard antioxidant ascorbic acid $\left(\mathrm{IC}_{50}=1.8 \pm 0.05 \mu \mathrm{g} / \mathrm{mL}\right.$ ) (Figure 2(b)).

3.2.2. Hemolytic Activity and Inhibition of Oxidative Hemolysis. Human erythrocytes incubated with the highest concentrations $(75 \mu \mathrm{g} / \mathrm{mL})$ of ascorbic acid (Figure 3(a)) or HEG (Figure 3(b)) did not show hemolysis, indicating that these compounds did not promote changes in this cellular model.

In the presence of the oxidizing agent AAPH, HEG protected the erythrocytes against oxidative hemolysis throughout the experimental period (Figure 3(b)). After $240 \mathrm{~min}$, HEG inhibited $80.9 \pm 5.6 \%$ of oxidative hemolysis at $75 \mu \mathrm{g} / \mathrm{mL}$, demonstrating superior antihemolytic action relative to that of ascorbic acid, which protected $67.6 \pm 4.5 \%$ of erythrocytes at the same concentration (Figure 3(a)).

3.2.3. Inhibition of $M D A$ Production. The ability of the extract to inhibit lipid peroxidation was assessed by measuring MDA levels. After $240 \mathrm{~min}, 75 \mu \mathrm{g} / \mathrm{mL} \mathrm{HEG}$ was able to reduce $\mathrm{MDA}$ levels by $81.2 \pm 10 \%$, whereas the standard antioxidant ascorbic acid inhibited $65.5 \pm 7.7 \%$ of MDA production at the same concentration (Figure 4).

3.3. Antimutagenic Activity. The HEG of M. q. anthidioides showed an antimutagenic effect on $S$. cerevisiae cells incubated with the mutagen EMS. HEG reduced the survival of $S$. cerevisiae D7 by approximately 50\% (Figure 5(a)), 


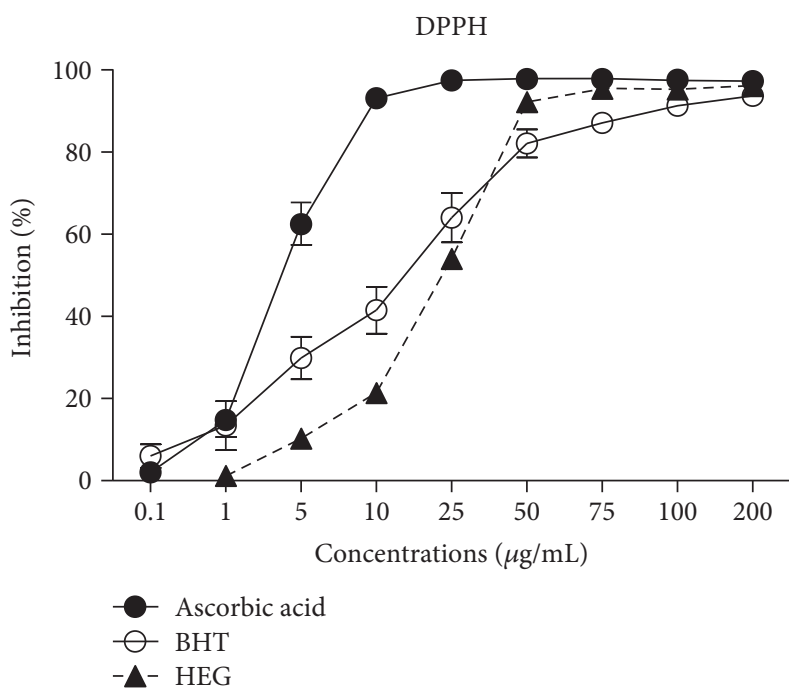

(a)

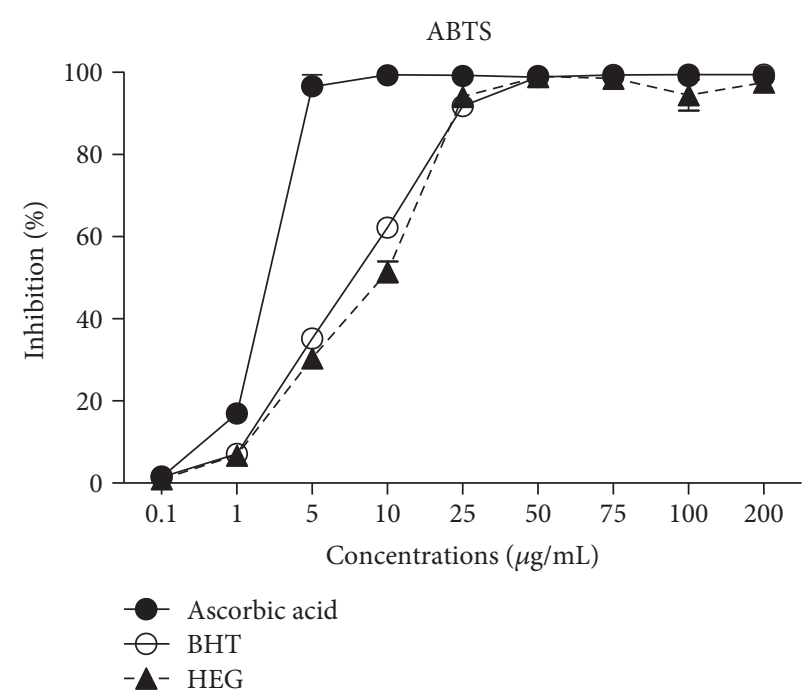

(b)

FIGURE 2: Antioxidant activity, as shown by scavenging of the free radicals (a) DPPH ${ }^{\bullet}$ and (b) ABTS $^{\bullet+}$ by the ascorbic acid and BHT controls and by the M. q. anthidioides geopropolis extract $(0.1-200 \mu \mathrm{g} / \mathrm{mL})$.

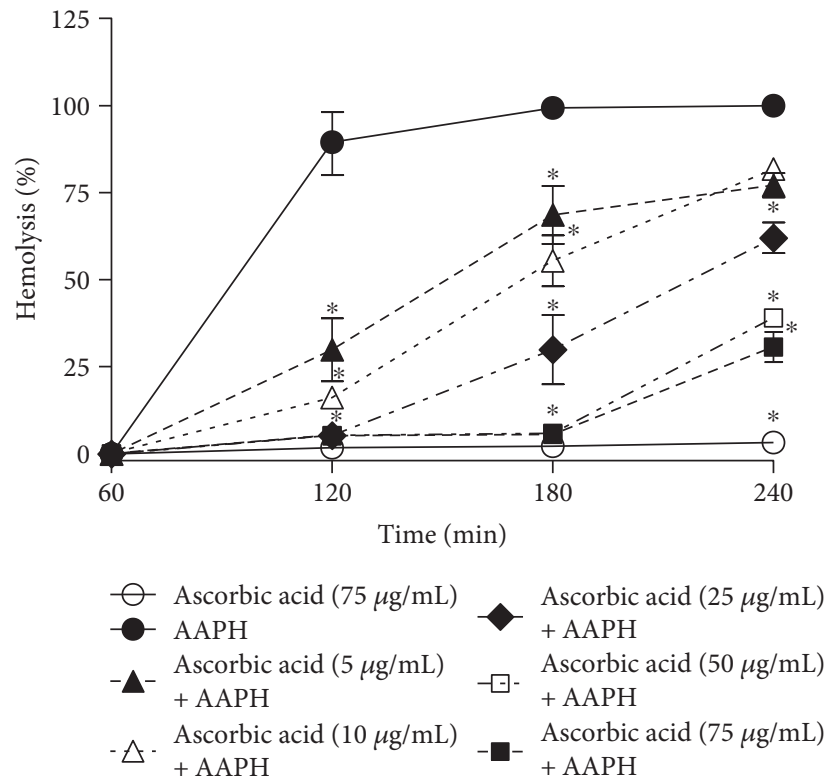

(a)

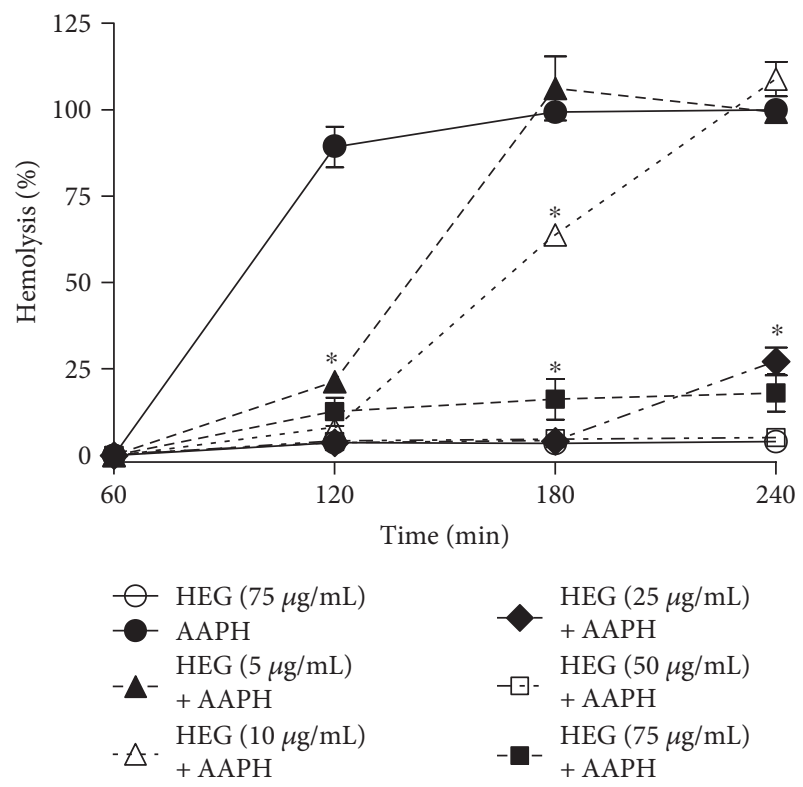

(b)

FIgURE 3: Inhibition of oxidative hemolysis in human erythrocytes incubated with (a) ascorbic acid and (b) HEG (5-125 $\mu \mathrm{g} / \mathrm{mL})$ in the presence of the oxidizing agent AAPH for $240 \mathrm{~min}$. * Statistically significant results $(P<0.05)$ compared to those of the AAPH control group at the same time point.

possibly because of its fungicidal action, and showed an antimutagenic effect by inhibiting the DNA damage promoted by EMS. The HEG reduced gene conversion frequencies by 30.7 $\pm 4.8 \%$ and $41.5 \pm 1.7 \%$ at concentrations of 1.5 and $3.0 \mathrm{mg}$ / $\mathrm{mL}$, respectively (Figure $5(\mathrm{~b})$ ). In addition, HEG reduced the number of mutant colonies by $79.4 \pm 0.8 \%$ at $1.5 \mathrm{mg} / \mathrm{mL}$ and by $89.3 \pm 0.5 \%$ at $3.0 \mathrm{mg} / \mathrm{mL}$ (Figure $5(\mathrm{c})$ ).

3.4. Anti-Inflammatory Activity. The anti-inflammatory activity of HEG was evaluated by testing its ability to inhibit hyaluronidase enzyme activity in the presence of its substrate, hyaluronic acid sodium salt. The extract showed a concentration-dependent profile, inhibiting $44.7 \pm 2.4 \%$ of hyaluronidase activity at $75 \mathrm{mg} / \mathrm{mL}$ (Figure 6).

3.5. Antimicrobial Activity. HEG showed antimicrobial activity against all of the tested microorganisms, including antimicrobial drug-resistant strains (Table 3). Gram-positive bacteria were more sensitive to HEG than were gramnegative species. The most sensitive microorganism was 


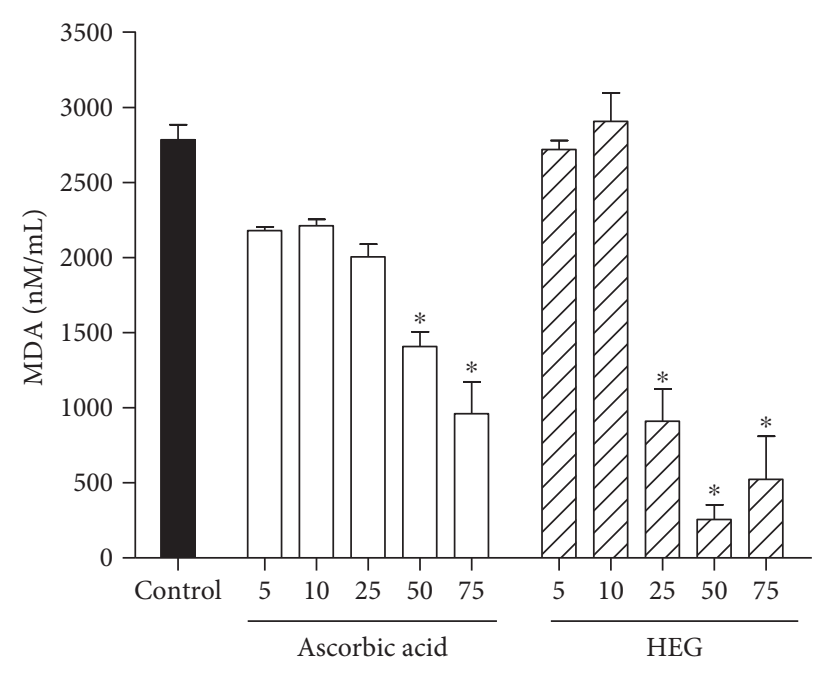

AAPH

FIgURE 4: Malondialdehyde concentration (MDA) in $\mathrm{nM} / \mathrm{mL}$ after incubation of erythrocytes for $240 \mathrm{~min}$ with ascorbic acid or HEG $(5-125 \mu \mathrm{g} / \mathrm{mL})$ in the presence of the oxidizing agent AAPH. * Statistically significant results $(P<0.05)$ compared to those of the AAPH control group.

Staphylococcus aureus ATCC 6538, which showed an MIC of $5.16 \pm 0.22 \mathrm{mg} / \mathrm{mL}$ and an $\mathrm{MBC}$ of $7.33 \pm 0.16 \mathrm{mg} / \mathrm{mL}$. The strain with the greatest resistance was the gram-negative bacterium Pseudomonas aeruginosa ESA 23, which is resistant to imipenem and originated from gingival exudate in a hospital setting; it showed an MIC of $12.75 \pm 0.28 \mathrm{mg} / \mathrm{mL}$ and an MBC of $16.41 \pm 0.36 \mathrm{mg} / \mathrm{mL}$.

HEG also exhibited antifungal activity against all of the tested yeasts, including reference strains and those of hospital origin. The strain most sensitive to the action of HEG was Cryptococcus neoformans ATCC 32264, and the most resistant strain was Candida albicans ESA 97, which is resistant to amphotericin $\mathrm{B}$ and is of hospital origin.

\section{Discussion}

The literature contains few scientific studies related to the chemical composition and pharmacological properties of geopropolis, an apicultural product with great pharmacological potential. In folk medicine, it is prescribed for the treatment of digestive, respiratory, and visual problems [33] and as an antiseptic [18]. These activities are related to the chemical composition of geopropolis, which is dependent on the local flora, the producing bee species, and the type of soil found in the region of geopropolis production $[1,3]$.

Phenolic heterosides, flavanones, and terpenoids were observed in the HEG; these compounds are frequently detected in Apis mellifera propolis [34,35] but have not often been described for Melipona geopropolis. An important finding was the presence of di- and trigalloyl and phenylpropanyl heteroside derivatives, which are rarely reported in the literature. Despite the paucity of reports, this class of compounds occurs in the kino of Eucalyptus spp. [36, 37], a common plant in the region where the geopropolis was collected. This observation may provide a clue about the source of raw material for the production of geopropolis by Melipona spp.

Other information about the origin of geopropolis came from a study performed by Sawaya et al. [38] with the stingless bee Tetragonisca angustula that reported compounds 19 and 20 in the propolis of this species and in the flowers and leaves of Schinus terebinthifolius. We analyzed the methanolic extract of the leaves of $S$. terebinthifolius from the same region where the geopropolis was collected and confirmed the presence of compound 20 (see Supplementary Material available online at https://doi.org/10.1155/2017/8320804). We conclude that $M$. q. anthidioides uses vegetal material from $S$. terebinthifolius to produce geopropolis. Flavanones and terpenes, the other two classes of identified compounds, are also normally present in apicultural plants [39-41], suggesting that Melipona spp. can use the same plants that Apis spp. use to produce propolis.

The phenolic compounds are described as important antioxidant agents $[7,26,30]$, and the content present in the HEG was approximately two times more than that present in geopropolis from other species of bees, as Melipona subnitida [1] and Melipona fasciculata [6]. Among the phenolic compounds identified in the HEG, the flavonoids methyl aromadendrin [42] and naringenin [43] are described as having antioxidant activities. In this study, HEG was able to scavenge the free radicals $\mathrm{DPPH}^{\bullet}$ and $\mathrm{ABTS}^{\bullet+}$, showing results similar to those presented by the geopropolis of $M$. subnitida [1] and higher compared to those by the geopropolis of the species Melipona interrupta and Melipona seminigra [16].

Moreover, HEG protected human erythrocytes against damage generated by the oxidizing agent AAPH, resulting in lower levels of both oxidative hemolysis and malondialdehyde (as a marker of lipid peroxidation). Flavonoids inhibit peroxyl radicals via the donation of hydrogen atoms, a process enabled by the presence of a dihydroxylated B ring in their structures [44]. Peroxyl radicals are involved in the lipid peroxidation process, which creates a number of degradation products, such as the aldehydes 4-hydroxy-2-nonenal, 2-propenal, and malondialdehyde [45]. Naringenin, one of the flavonoids identified in HEG, has been described as modulating the activity of the enzymes superoxide dismutase, glutathione peroxidase, and catalase, in addition to protecting the cell membrane against the lipid peroxidation process by inhibiting the production of malondialdehyde and increasing the content of thiol-SH groups [43]. In turn, diterpenes promote the scavenging of free radicals, which results in the inhibition of lipid peroxidation $[46,47]$.

Lipid peroxidation resulting from elevated cellular oxidative stress is capable of promoting damage to proteins and nucleic acids, which may constitute the first steps of mutagenesis and carcinogenesis [48, 49]. With this perspective, after confirming the antioxidant activity of HEG from $M$. q. anthidioides, its antimutagenic properties were investigated. The HEG minimized the damage induced by the EMS alkylating agent, which induces random mutations in DNA by nucleotide substitution [31]. The antimutagenic activity of the HEG was similar to that of the geopropolis 


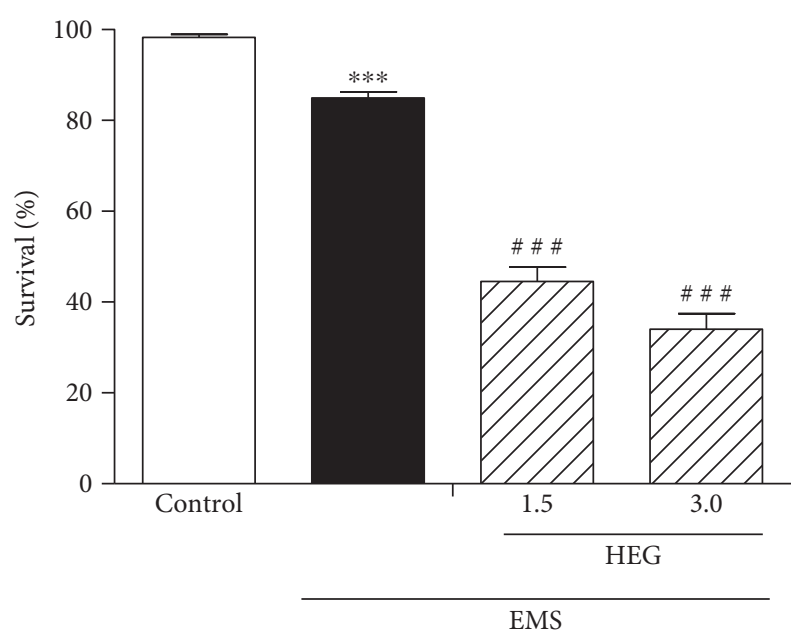

(a)

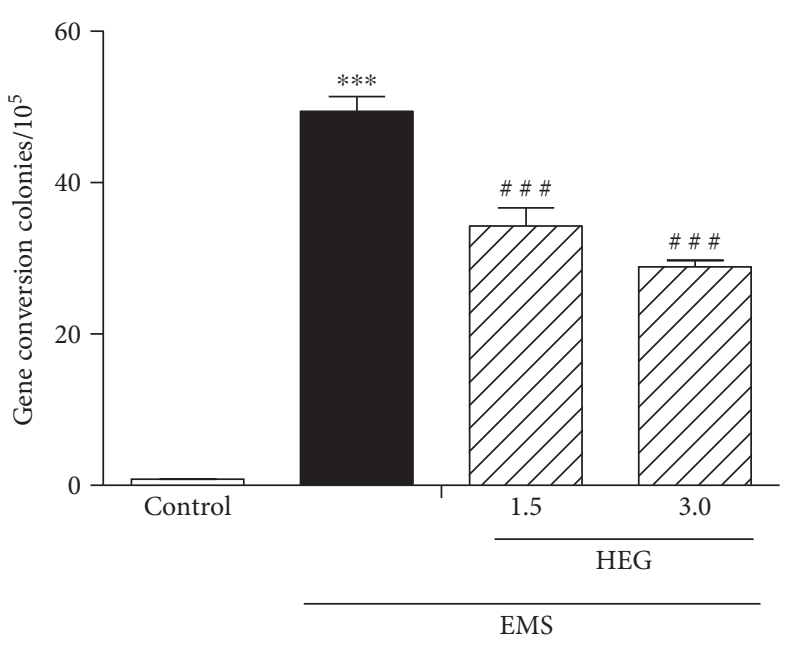

(b)

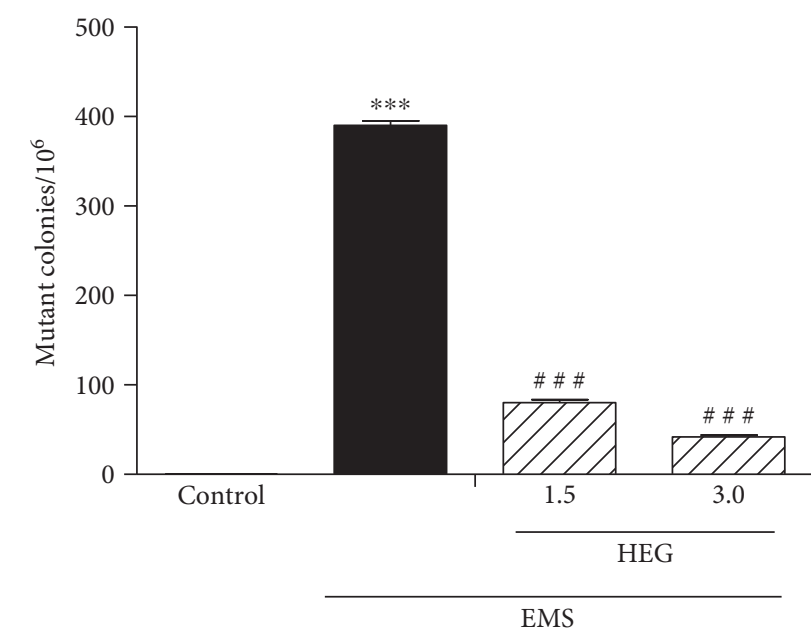

(c)

Figure 5: S. cerevisiae yeast cells (D7 diploid strain of ATCC 201137) incubated with HEG (1.5 and $3.0 \mathrm{mg} / \mathrm{mL}$ ) and the mutagen EMS. (a) Survival percentage, (b) gene conversion, and (c) mutant colonies are shown. ${ }^{* * *} P<0.0001$ compared to the control. ${ }^{\# \# \# P}<0.0001$ compared to the EMS control.

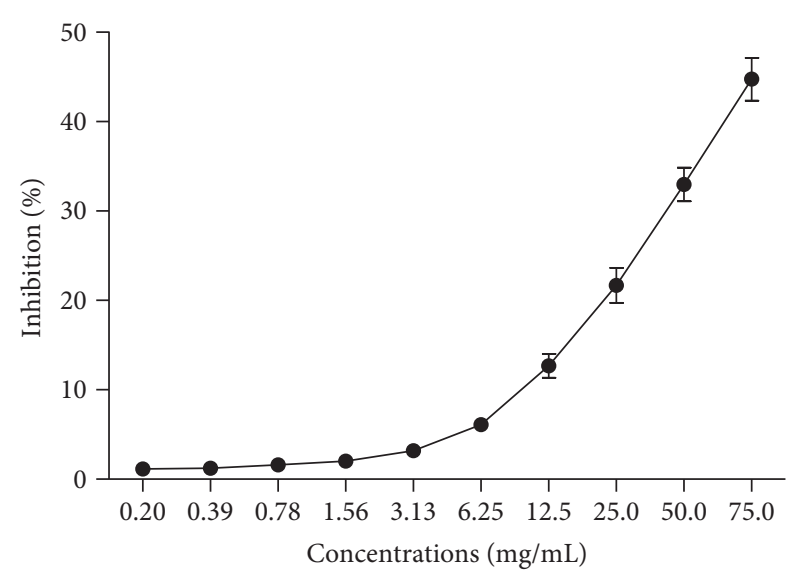

Figure 6: Inhibition of the inflammatory enzyme hyaluronidase by HEG $(0.2-75 \mathrm{mg} / \mathrm{mL})$. extract of Melipona orbignyi, regarding the reduction of mutant colonies; however, it was more effective against the gene conversion [7].

Living organisms have mutation repair mechanisms; however, they are often unable to correct all of the changes that occur, leaving the cell vulnerable to the development of problems related to DNA alterations [50]. Certain changes in the genetic material of cells are related to the development of cancer [51, 52]. Thus, products with antimutagenic activities can aid in preventing various types of cancers.

In addition to its antioxidant and antimutagenic activities, there are reports in the literature about the antiinflammatory action of geopropolis, both in vitro and in vivo, via modulation of the main inflammatory mediators $[12,14]$. In this study, HEG showed anti-inflammatory action in its inhibition of hyaluronic acid degradation by the hyaluronidase enzyme. Hyaluronic acid is a polysaccharide found primarily in the extracellular and pericellular 
TABLE 3: MIC and MBC/MFC values for HEG from M. q. anthidioides.

(a)

\begin{tabular}{|c|c|c|c|c|}
\hline \multirow{2}{*}{ Microorganisms } & \multicolumn{2}{|c|}{ HEG $(\mathrm{mg} / \mathrm{mL})$} & \multicolumn{2}{|c|}{ Gentamicin $(\mu \mathrm{g} / \mathrm{mL})$} \\
\hline & MIC & MBC & MIC & MBC \\
\hline \multicolumn{5}{|l|}{ Gram-positive bacteria } \\
\hline Staphylococcus aureus ATCC 6538 & $5.16 \pm 0.22$ & $7.33 \pm 0.16$ & $1.66 \pm 0.16$ & $2.0 \pm 0.28$ \\
\hline Methicillin-resistant S. aureus ESA 175 & $5.75 \pm 0.14$ & $7.83 \pm 0.16$ & $1.83 \pm 0.16$ & $2.66 \pm 0.16$ \\
\hline Methicillin-resistant S. aureus ESA 159 & $6.25 \pm 0.14$ & $8.08 \pm 0.22$ & $2.0 \pm 0.28$ & $2.50 \pm 0.28$ \\
\hline Enterococcus faecalis ATCC 43300 & $6.75 \pm 0.14$ & $8.75 \pm 0.25$ & $2.16 \pm 0.16$ & $2.83 \pm 0.30$ \\
\hline Vancomycin-resistant E. faecalis ESA 201 & $7.33 \pm 0.83$ & $9.50 \pm 0.28$ & $2.33 \pm 0.16$ & $3.25 \pm 0.14$ \\
\hline Vancomycin-resistant E. faecalis ESA 361 & $7.58 \pm 0.30$ & $9.91 \pm 0.54$ & $2.66 \pm 0.16$ & $3.33 \pm 0.16$ \\
\hline \multicolumn{5}{|l|}{ Gram-negative bacteria } \\
\hline Escherichia coli ATCC 29998 & $9.66 \pm 0.44$ & $13.0 \pm 0.14$ & $4.08 \pm 0.08$ & $4.58 \pm 0.30$ \\
\hline Cephalosporin-resistant E. coli ESA 37 & $10.25 \pm 0.52$ & $13.16 \pm 0.44$ & $4.66 \pm 0.16$ & $4.66 \pm 0.22$ \\
\hline Cephalosporin-resistant E. coli ESA 54 & $10.25 \pm 0.25$ & $13.33 \pm 0.36$ & $4.41 \pm 0.08$ & $4.91 \pm 0.08$ \\
\hline Pseudomonas aeruginosa ATCC 15442 & $11.91 \pm 0.36$ & $15.41 \pm 0.36$ & $4.75 \pm 0.14$ & $5.0 \pm 0.28$ \\
\hline Imipenem-resistant $P$. aeruginosa ESA 22 & $12.16 \pm 0.60$ & $15.41 \pm 0.30$ & $5.66 \pm 0.16$ & $6.61 \pm 0.16$ \\
\hline Imipenem-resistant $P$. aeruginosa ESA 23 & $12.75 \pm 0.28$ & $16.41 \pm 0.36$ & $6.66 \pm 0.33$ & $6.50 \pm 0.28$ \\
\hline
\end{tabular}

(b)

\begin{tabular}{lccr}
\hline Microorganisms & \multicolumn{2}{c}{ HEG $(\mathrm{mg} / \mathrm{mL})$} & \multicolumn{2}{c}{ Amphotericin B $(\mu \mathrm{g} / \mathrm{mL})$} \\
MFC
\end{tabular}

matrix as a component of soft connective tissues [53], where it has an important role in tissue renewal [32]. The degradation of hyaluronic acid by hyaluronidase results in tissue permeability [54], bone loss, inflammation, and pain $[31,54]$.

The inhibition of hyaluronidase activity by HEG may be related to the presence of flavonoids in its composition, as they have been described as reducing hyaluronidase activity by binding to the enzyme and promoting structural alterations by means of electrostatic forces and hydrophobic interactions [55]. In addition, the flavonoids identified in HEG, naringenin and 7-O-methylaromadendrin, reportedly inhibit the activity of the cyclooxygenase 1 enzyme, and aromadendrin inhibits the activity of xanthine oxidase [56]; these enzymes are directly related to inflammatory processes.

Another important pharmacological activity exhibited by HEG was its antimicrobial action against both reference and clinical strains. HEG promoted the death of all of the tested gram-positive bacteria, gram-negative bacteria, and yeasts. Previous studies by Kujumgiev et al. [24] and Velikova et al. [25] described the antimicrobial potential of propolis from M. q. anthidioides; however, this is the first report to show that the geopropolis of this bee subspecies can combat pathogenic microorganisms.

The identification of new compounds with antimicrobial action has aroused the interest of the pharmaceutical industry, especially because many strains of microorganisms have become resistant to currently available antimicrobial drugs, thereby resulting in high morbidity and mortality rates, especially among nosocomial infections [57, 58]. Among the main mechanisms of resistance are the elimination of antibiotics by efflux pumps present in the cell wall of microorganisms [59, 60] and the degradation of antibiotics by specific enzymes [61].

Natural products represent a good source for the discovery of bioactive compounds with high antimicrobial activity, especially considering the complexity of the molecules present in these bioproducts [62]. The antimicrobial properties of geopropolis from other bee species have been described in other studies with Melipona fasciculata [2, 63], Melipona orbignyi [7], Melipona scutellaris [10, 11], and Melipona mondury [64], as well as the subspecies Melipona compressipes fasciculate [65]. 
Among the chemical compounds described as responsible for the antimicrobial activity of natural products are the flavonoids [66, 67]. In bacteria, they are capable of inhibiting DNA gyrase [68], damaging cell membranes by reducing their fluidity [69] and decreasing microbial energy metabolism [66]; these mechanisms are responsible for their antibacterial effects. In addition to these, diterpenes are also described as having antimicrobial activity, as they easily penetrate the cell membranes of microorganisms and create pores that result in the loss of intracellular contents [44].

In this context, this study is the first to report the chemical composition and pharmacological activities of the geopropolis extract of $M$. q. anthidioides, a natural product of apicultural origin that has great potential to be used in the prevention and treatment of several diseases related to oxidative stress, mutagenesis, inflammatory processes, and microbial infections.

\section{Conflicts of Interest}

The authors declare that there are no conflicts of interest.

\section{Acknowledgments}

This work was supported by grants from Fundação de Apoio ao Desenvolvimento do Ensino, Ciência e Tecnologia do Estado de Mato Grosso do Sul (FUNDECT), Coordenação de Aperfeiçoamento de Pessoal de Nível Superior (CAPES), Conselho Nacional de Desenvolvimento Científico e Tecnológico $(\mathrm{CNPq})$, Universidade Federal da Grande Dourados (UFGD), and PRODER (24.073 - Â, Portugal).

\section{References}

[1] S. Alves de Souza, C. A. Camara, E. Monica Sarmento da Silva, and T. M. Silva, "Composition and antioxidant activity of geopropolis collected by Melipona subnitida (Jandaíra) bees," Evidence-Based Complementary and Alternative Medicine, vol. 2013, Article ID 801383, 5 pages, 2013.

[2] S. A. Liberio, A. L. A. Pereira, R. P. Dutra et al., "Antimicrobial activity against oral pathogens and immunomodulatory effects and toxicity of geopropolis produced by the stingless bee Melipona fasciculate Smith," BMC Complementary and Alternative Medicine, vol. 11, pp. 1-10, 2011.

[3] M. Araujo, M. Bufalo, B. Conti et al., "The chemical composition and pharmacological activities of geopropolis produced by Melipona fasciculata Smith in Northeast Brazil," Journal of Molecular Pathophysiology, vol. 4, no. 1, pp. 12-20, 2015.

[4] P. Nogueira-Neto, Vida e criação de abelhas indígenas sem ferrão, Nogueirapis, São Paulo, Brazil, 1st edition, 1997.

[5] M. G. da Cunha, P. L. Rosalen, M. Franchin et al., "Antiproliferative constituents of geopropolis from the bee Melipona scutellaris," Planta Medica, vol. 82, pp. 190-194, 2016.

[6] R. P. Dutra, B. V. Abreu, M. S. Cunha et al., "Phenolic acids, hydrolyzable tannins, and antioxidant activity of geopropolis from the stingless bee Melipona fasciculata Smith," Journal of Agricultural and Food Chemistry, vol. 62, no. 12, pp. 25492557, 2014.

[7] H. F. D. Santos, J. F. Campos, C. M. D. Santos et al., "Chemical profile and antioxidant, anti-inflammatory, antimutagenic and antimicrobial activities of geopropolis from the stingless bee Melipona orbignyi," International Journal of Molecular Sciences, vol. 18, no. 5, 2017.

[8] V. Bankova, R. Christov, C. Marcucci, and S. Popov, "Constituents of Brazilian geopropolis," Zeitschrift fur Naturforschung C: Journal of Biosciences, vol. 53c, pp. 402-406, 1998.

[9] V. Bankova, S. L. Castro, and M. C. Marcucci, "Propolis: recent advances in chemistry and plant origin," Apidologie, vol. 31, pp. 3-15, 2000.

[10] M. G. da Cunha, M. Franchin, L. C. Galvão et al., “Apolar bioactive fraction of Melipona scutellaris geopropolis on Streptococcus mutans biofilm," Evidence-Based Complementary and Alternative Medicine, vol. 2013, Article ID 256287, 7 pages, 2013.

[11] M. G. da Cunha, M. Franchin, L. C. de Carvalho Galvão et al., "Antimicrobial and antiproliferative activities of stingless bee Melipona scutellaris geopropolis," BMC Complementary and Alternative Medicine, vol. 13, no. 1, 2013.

[12] M. Franchin, M. G. da Cunha, C. Denny et al., "Bioactive fraction of geopropolis from Melipona scutellaris decreases neutrophils migration in the inflammatory process: involvement of nitric oxide pathway," Evidence-Based Complementary and Alternative Medicine, vol. 2013, Article ID 907041, 9 pages, 2013.

[13] M. Franchin, P. L. Rosalen, M. G. da Cunha et al., "Cinnamoyloxy-mammeisin isolated from geopropolis attenuates inflammatory process by inhibiting cytokine production: involvement of MAPK, AP-1, and NF- $\kappa$ B," Journal of Natural Products, vol. 79, pp. 1828-1833, 2016.

[14] M. Franchin, M. G. da Cunha, C. Denny et al., "Geopropolis from Melipona scutellaris decreases the mechanical inflammatory hypernociception by inhibiting the production of IL- $1 \beta$ and TNF- $\alpha$," Journal of Ethnopharmacology, vol. 143, no. 2, pp. 709-715, 2012.

[15] J. A. Ribeiro-Junior, M. Franchin, M. E. Cavallini et al., "Gastroprotective effect of geopropolis from Melipona scutellaris is dependent on production of nitric oxide and prostaglandin," Evidence-Based Complementary and Alternative Medicine, vol. 2015, Article ID 459846, 5 pages, 2015.

[16] E. C. C. Silva, M. P. Muniz, R. C. S. Nunomura, S. M. Nunomura, and G. A. C. Zilse, "Phenolic constituents and antioxidant activity of geopropolis from two species of amazonian stingless bees," Química Nova, vol. 36, pp. 628633, 2013.

[17] N. C. Cinegaglia, P. R. O. Bersano, M. J. A. M. Araújo, M. C. Búfalo, and J. M. Sforcin, "Anticancer effects of geopropolis produced by stingless bees on canine osteosarcoma cells in vitro," Evidence-Based Complementary and Alternative Medicine, vol. 2013, Article ID 737386, 6 pages, 2013.

[18] A. R. Bartolomeu, Y. Frión-Herrera, L. M. da Silva, G. G. Romagnoli, D. E. de Oliveira, and J. M. Sforcin, "Combinatorial effects of geopropolis produced by Melipona fasciculata Smith with anticancer drugs against human laryngeal epidermoid carcinoma (HEp-2) cells," Biomedicine \& Pharmacother$a p y$, vol. 81, pp. 48-55, 2016.

[19] A. M. Waldschmidt, P. Marco-Júnior, E. G. Barros, and L. A. Campos, "Genetic analysis of Melipona quadrifasciata Lep (Hymenoptera: Apidae, Meliponinae) with RAPD markers," Brazilian Journal of Biology, vol. 62, pp. 923928, 2002.

[20] J. M. F. Camargo and S. R. M. Pedro, "Meliponini Lepeletier, 1836. In (Hymenoptera, Apoidea) in the Neotropical Region," 2016, http://www.moure.cria.org.br/catalogue. 
[21] L. Z. Pinto, M. A. Laure, M. M. Bitondi, K. Hartfelder, and Z. L. Simões, "Ventral nerve cord remodeling in a stingless bee (Melipona quadrifasciata anthidioides, Hymenoptera, Apidae) depends on ecdysteroid fluctuation and programmed cell death," The International Journal of Developmental Biology, vol. 47, no. 5, pp. 385-388, 2003.

[22] L. A. Nunes, G. B. Passos, C. A. Carvalho, and E. D. Araújo, "Size and shape in Melipona quadrifasciata anthidioides Lepeletier, 1836 (Hymenoptera; Meliponini)," Brazilian Journal of Biology, vol. 73, no. 4, pp. 887-893, 2013.

[23] M. G. Tavares, N. T. Pietrani, M. de Castro Durvale, H. C. Resende, and L. A. de Oliveira Campos, "Genetic divergence between Melipona quadrifasciata Lepeletier (Hymenoptera, Apidae) populations," Genetics and Molecular Biology, vol. 36, no. 1, pp. 111-117, 2013.

[24] A. Kujumgiev, I. Tsvetkova, Y. Serkedjieva, V. Bankova, R. Christov, and S. Popov, "Antibacterial, antifungal and antiviral activity of propolis of different geographic origin," Journal of Ethnopharmacology, vol. 64, pp. 235-240, 1999.

[25] M. Velikova, V. Bankova, I. Tsvetkova, A. Kujumgiev, and M. C. Marcucci, "Antibacterial ent-kaurene from Brazilian propolis of native stingless bees," Fitoterapia, vol. 71, pp. 693-696, 2000.

[26] T. Bonamigo, J. F. Campos, T. M. Alfredo et al., "Antioxidant, cytotoxic, and toxic activities of two types of propolis from native bees in Brazil: Scaptotrigona depilis and Melipona quadrifasciata anthidioides," Oxidative Medicine and Cellular Longevity, vol. 2017, Article ID 1038153, 12 pages, 2017.

[27] A. Meda, C. E. Lamien, M. Romito, J. Millogo, and O. G. Nacoulma, "Determination of the total phenolic, flavonoid and proline contents in Burkina Fasan honey, as well as their radical scavenging activity," Food Chemistry, vol. 91, pp. 571-577, 2005.

[28] D. Gupta and R. K. Gupta, "Bioprotective properties of dragon's blood resin: in vitro evaluation of antioxidant activity and antimicrobial activity," BMC Complementary and Alternative Medicine, vol. 11, p. 13, 2011.

[29] R. Re, N. Pellegrini, A. Proteggente, A. Pannala, M. Yang, and C. Rice-Evans, "Antioxidant activity applying an improved ABTS radical cation decolorization assay," Free Radical Biology \& Medicine, vol. 26, pp. 1231-1237, 1999.

[30] J. F. Campos, U. P. Dos Santos, S. da Rocha Pdos et al., "Antimicrobial, antioxidant, anti-inflammatory, and cytotoxic activities of propolis from the stingless bee Tetragonisca fiebrigi (Jataí)," Evidence-Based Complementary and Alternative Medicine, vol. 2015, Article ID 296186, 11 pages, 2015.

[31] A. Pascoal, S. Rodrigues, A. Teixeira, X. Feás, and L. M. Estevinho, "Biological activities of commercial bee pollens: antimicrobial, antimutagenic, antioxidant and anti-inflammatory," Food and Chemical Toxicology, vol. 63, pp. 233239, 2014.

[32] J. C. Silva, S. Rodrigues, X. Feás, and L. M. Estevinho, “Antimicrobial activity, phenolic profile and role in the inflammation of propolis," Food and Chemical Toxicology, vol. 50, pp. 1790-1795, 2012.

[33] M. O. Freitas, F. A. Ponte, M. A. S. Lima, and E. R. Silveira, "Flavonoids and triterpenes from the nest of the stingless bee Trigona spinipes," Journal of the Brazilian Chemical Society, vol. 19 , pp. 532-535, 2008.
[34] C. Gardana, M. Scaglianti, P. Pietta, and P. Simonetti, "Analysis of the polyphenolic fraction of propolis from different sources by liquid chromatography-tandem mass spectrometry," Journal of Pharmaceutical and Biomedical Analysis, vol. 45, pp. 390-399, 2007.

[35] F. Pellati, G. Orlandini, D. Pinetti, and S. Benvenuti, "HPLC-DAD and HPLC-ESI-MS/MS methods for metabolite profiling of propolis extracts," Journal of Pharmaceutical and Biomedical Analysis, vol. 55, no. 5, pp. 934-948, 2011.

[36] M. O. Freitas, M. A. S. Lima, and E. R. Silveira, "Polyphenol compounds of the kino of Eucalyptus citriodora," Química Nova, vol. 30, pp. 1926-1929, 2007.

[37] O. A. Rashwan, "New phenylpropanoid glucosides from Eucalyptus maculata," Molecules, vol. 7, pp. 75-80, 2002.

[38] A. Sawaya, I. B. S. Cunha, M. C. Marcucci, R. F. de Oliveira Rodrigues, and M. N. Eberlin, "Brazilian propolis of Tetragonisca angustula and Apis mellifera," Apidologie, vol. 37, pp. 398-407, 2006.

[39] Y. Nagatani, T. Warashina, and T. Noro, "Studies on the constituents from the aerial part of Baccharis dracunculifolia DC," Chemical and Pharmaceutical Bulletin, vol. 49, pp. 1388-1394, 2001.

[40] Y. Nagatani, T. Warashina, and T. Noro, "Studies on the constituents from the aerial part of Baccharis dracunculifolia DC. II," Chemical and Pharmaceutical Bulletin, vol. 50, pp. 583-589, 2002.

[41] P. R. V. Ribeiro, D. de Castro Girão, A. T. Á. Pimenta et al., "Clerodane and patchoulene terpenes as new constituents from Baccharis salzmannii DC," Biochemical Systematics and Ecology, vol. 50, pp. 101-105, 2013.

[42] P. S. Rajesh, P. V. Samaga, V. R. Rai, and K. M. Rai, "In vitro biological activity of aromadendrin-40-methyl ether isolated from root extract of Ventilago madraspatana Gaertn with relevance to anticandidal activity," Natural Product Research, vol. 29, no. 11, pp. 1042-1045, 2014.

[43] M. Miler, J. Živanović, V. Ajdžanović et al., "Citrus flavanones naringenin and hesperetin improve antioxidant status and membrane lipid compositions in the liver of old-aged Wistar rats," Experimental Gerontology, vol. 84, pp. 49-60, 2016.

[44] M. Valko, C. J. Rhodes, J. Moncol, M. Izakovic, and M. Mazur, "Free radicals, metals and antioxidants in oxidative stressinduced cancer," Chemico-Biological Interactions, vol. 160, pp. 1-40, 2006.

[45] I. Dalle-Donne, R. Rossi, R. Colombo, D. Giustarini, and A. Milzani, "Biomarkers of oxidative damage in human disease," Clinical Chemistry, vol. 52, pp. 601-623, 2006.

[46] V. K. Bajpai, A. Sharma, S. C. Kang, and K. H. Baek, "Antioxidant, lipid peroxidation inhibition and free radical scavenging efficacy of a diterpenoid compound sugiol isolated from Metasequoia glyptostroboides," Asian Pacific Journal of Tropical Medicine, vol. 7, pp. 9-15, 2014.

[47] M. R. de Oliveira, G. da Costa Ferreira, A. Peres, and S. M. Bosco, "Carnosic acid suppresses the $\mathrm{H}_{2} \mathrm{O}_{2}$-induced mitochondria-related bioenergetics disturbances and redox impairment in SH-SY5Y cells: role for Nrf2," Molecular Neurobiology, vol. 2017, pp. 1-12, 2017.

[48] M. Valko, D. Leibfritz, J. Moncol, M. T. Cronin, M. Mazur, and J. Telser, "Free radicals and antioxidants in normal physiological functions and human disease," The International Journal of Biochemistry \& Cell Biology, vol. 39, pp. 44-84, 2007. 
[49] S. Boiteux and S. Jinks-Robertson, "DNA repair mechanisms and the bypass of DNA damage in Saccharomyces cerevisiae," Genetics, vol. 193, pp. 1025-1064, 2013.

[50] S. Clancy, "DNA damage \& repair: mechanisms for maintaining DNA integrity," Nature Education, vol. 1, no. 1, p. 103, 2008, https://www.nature.com/scitable/topicpage/dnadamage-repair-mechanisms-for-maintaining-dna-344.

[51] K. R. Loeb and L. A. Loeb, "Significance of multiple mutations in cancer," Carcinogenesis, vol. 21, no. 3, pp. 379-385, 2000.

[52] P. Karran and R. Brem, "Protein oxidation, UVA and human DNA repair," DNA Repair, vol. 44, pp. 178-185, 2016.

[53] J. Necas, L. Bartosikova, P. Brauner, and J. Kolar, "Hyaluronic acid (hyaluronan): a review," Veterinární Medicína, vol. 53, pp. 397-411, 2008.

[54] C. Bauer, E. Niculescu-Morzsa, V. Jeyakumar, D. Kern, S. S. Späth, and S. Nehrer, "Chondroprotective effect of high-molecular-weight hyaluronic acid on osteoarthritic chondrocytes in a co-cultivation inflammation model with M1 macrophages," Journal of Inflammation, vol. 13, p. 31, 2016.

[55] H. J. Zeng, J. Ma, R. Yang, Y. Jing, and L. B. Qu, "Molecular interactions of flavonoids to hyaluronidase: insights from spectroscopic and molecular modeling studies," Journal of Fluorescence, vol. 25, pp. 941-959, 2015.

[56] H. J. Zeng, J. Ma, R. Yang, Y. Jing, and L. B. Qu, “Antiinflammatory activity of flavonoids from Populus davidiana," Archives of Pharmacal Research, vol. 29, pp. 1102-1110, 2006.

[57] A. M. Gonzalez-Villoria and V. Valverde-Garduno, "Antibiotic-resistant Acinetobacter baumannii increasing success remains a challenge as a nosocomial pathogen," Journal of Pathogens, vol. 2016, Article ID 7318075, 10 pages, 2016.

[58] C. Feldman and R. Anderson, "Epidemiology, virulence factors and management of the pneumococcus," F1000 Research, vol. 5, p. 2320, 2016.

[59] R. O'Shea and H. E. Moser, "Physicochemical properties of antibacterial compounds: implications for drug discovery," Journal of Medicinal and Pharmaceutical Chemistry, vol. 51, pp. 2871-2878, 2008.

[60] D. G. Brown, T. Lister, and T. L. May-Dracka, "New natural products as new leads for antibacterial drug discovery," Bioorganic \& Medicinal Chemistry Letters, vol. 24, pp. 413-418, 2014.

[61] J. L. M. Sampaio and A. C. Gales, "Antimicrobial resistance in Enterobacteriaceae in Brazil: focus on $\beta$-lactams and polymyxins," Brazilian Journal of Microbiology, vol. 47, pp. 31-37, 2016.

[62] M. A. Hayashi, F. C. Bizerra, and P. I. S. J. Silva, "Antimicrobial compounds from natural sources," Frontiers in Microbiology, vol. 4, 2013.

[63] M. J. A. M. Araújo, S. M. G. Bosco, and J. M. Sforcin, "Pythium insidiosum: inhibitory effects of propolis and geopropolis on hyphal growth," Brazilian Journal of Microbiology, vol. 47, pp. 863-869, 2016.

[64] T. L. A. D. Santos, R. F. Queiroz, A. C. H. F. Sawaya et al., "Melipona mondury produces a geopropolis with antioxidant, antibacterial and antiproliferative activities," Annals of the Brazilian Academy of Sciences, vol. 2017, pp. 1-13, 2017.

[65] S. A. Duailibe, A. G. Gonçalves, and F. J. Ahid, "Effect of a propolis extract on Streptococcus mutans counts in vivo," Journal of Applied Oral Science, vol. 15, pp. 420-423, 2007.
[66] T. P. T. Cushnie and A. J. Lamb, "Recent advances in understanding the antibacterial properties of flavonoids," The International Journal of Antimicrobial Agents, vol. 38, pp. 99-107, 2011.

[67] M. He, T. Wu, S. Pan, and X. Xu, "Antimicrobial mechanism of flavonoids against Escherichia coli ATCC 25922 by model membrane study," Applied Surface Science, vol. 305, pp. 515521,2014

[68] T. Wu, X. Zang, M. He, S. Pan, and X. Xu, "Structure-activity relationship of flavonoids on their anti-Escherichia coli activity and inhibition of DNA gyrase," Journal of Agricultural and Food Chemistry, vol. 61, pp. 8185-8190, 2013.

[69] H. Tsuchiya and M. Iinuma, "Reduction of membrane fluidity by antibacterial sophoraflavanone G isolated from Sophora exigua," Phytomedicine, vol. 7, pp. 161-165, 2000. 


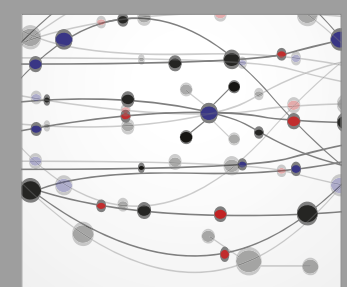

The Scientific World Journal
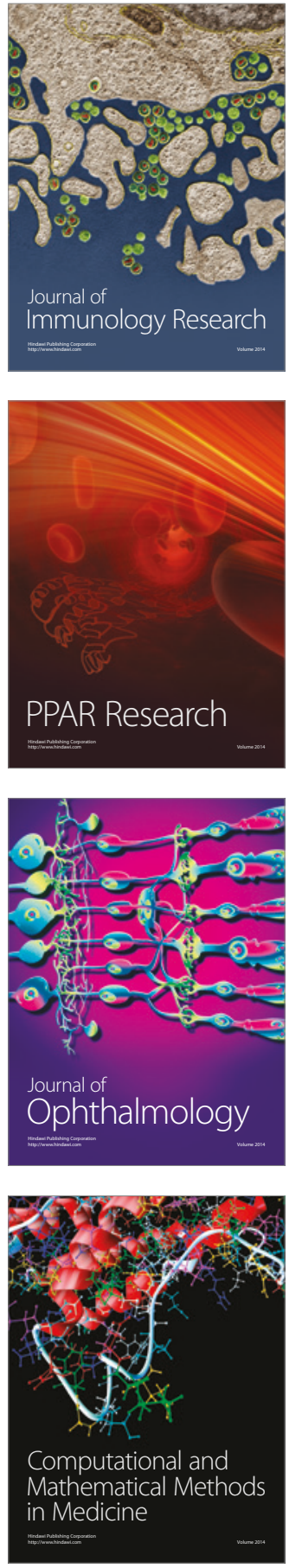

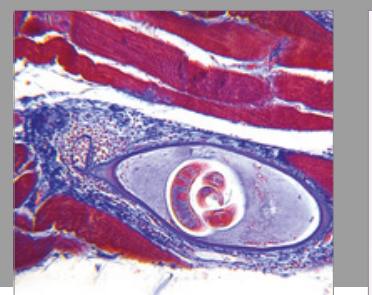

Gastroenterology Research and Practice
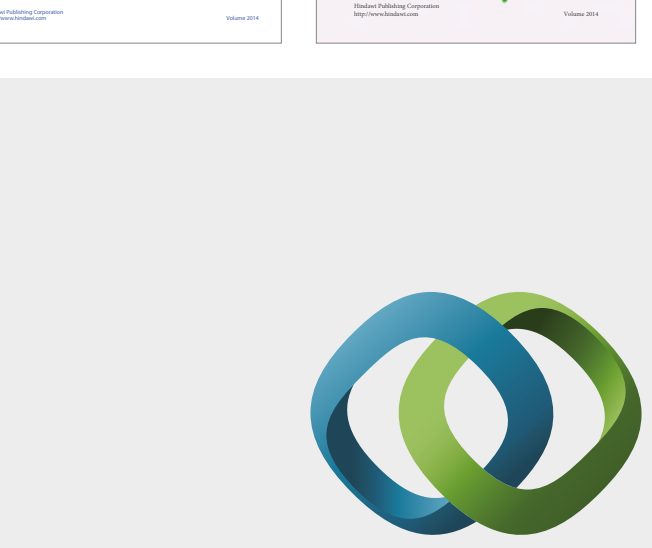

\section{Hindawi}

Submit your manuscripts at

https://www.hindawi.com
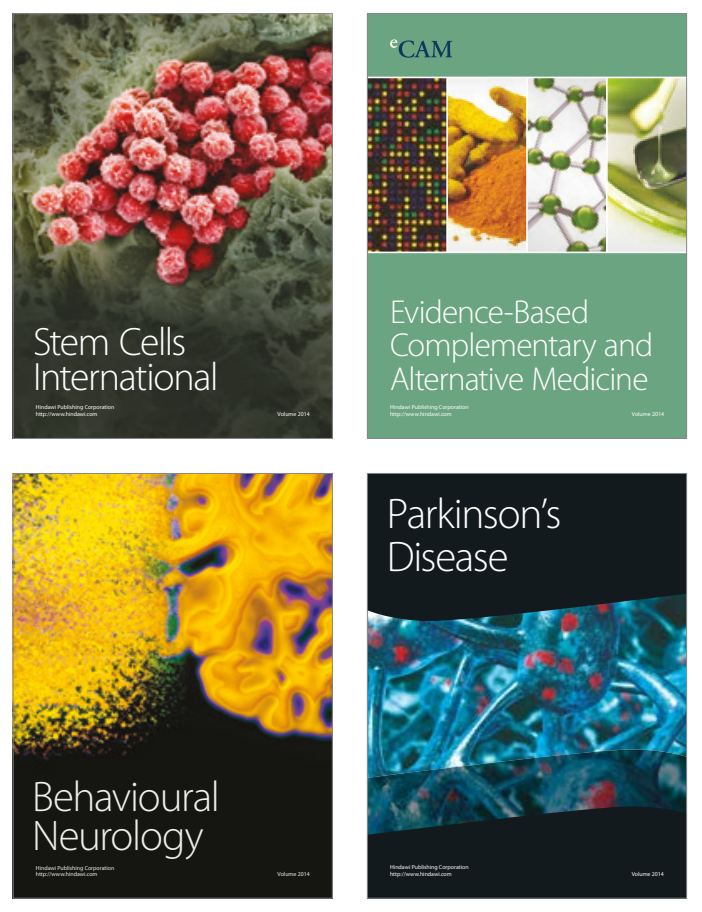
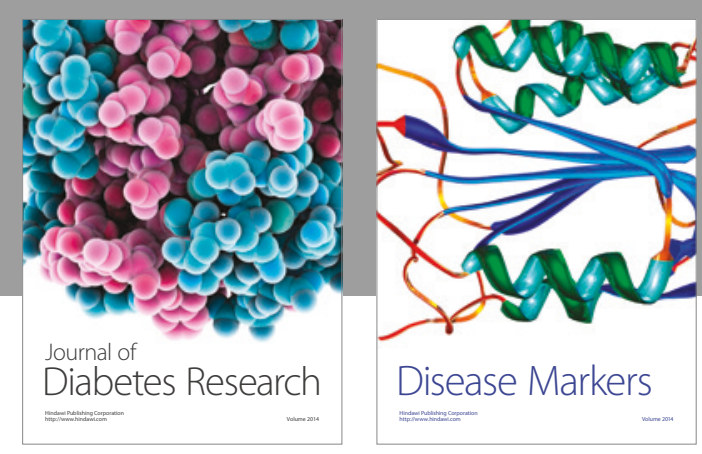

Disease Markers
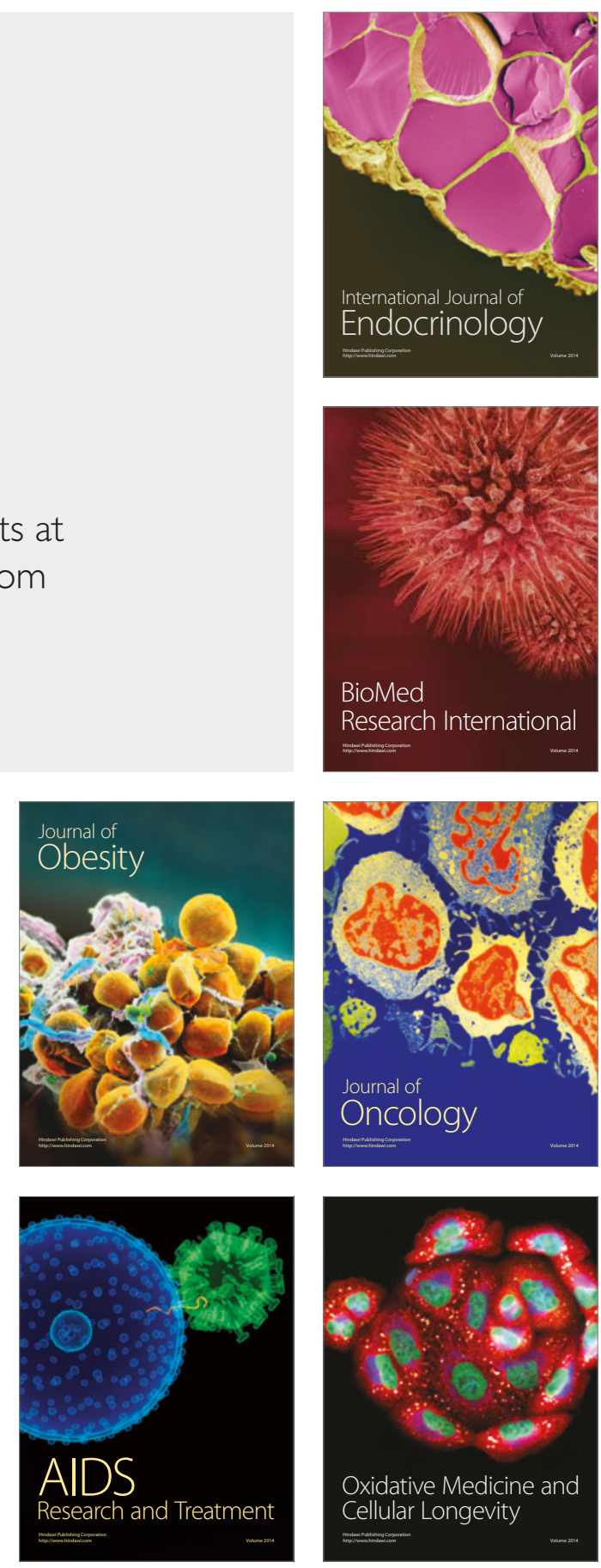